\title{
Cylindrocarpon root rot: multi-gene analysis reveals novel species within the Ilyonectria radicicola species complex
}

\author{
Ana Cabral • Johannes Z. Groenewald • Cecília Rego • \\ Helena Oliveira $\cdot$ Pedro W. Crous
}

Received: 29 March 2011 /Revised: 2 July 2011 / Accepted: 11 July 2011 /Published online: 27 July 2011

(C) The Author(s) 2011. This article is published with open access at Springerlink.com

\begin{abstract}
Ilyonectria radicicola and its Cylindrocarpon-like anamorph represent a species complex that is commonly associated with root rot disease symptoms on a range of hosts. During the course of this study, several species could be distinguished from I. radicicola sensu stricto based on morphological and culture characteristics. DNA sequence analysis of the partial $\beta$-tubulin, histone $\mathrm{H} 3$, translation elongation factor $1-\alpha$ and nuclear ribosomal RNA-Internal Transcribed Spacer (nrRNA-ITS) genes were employed to provide further support for the morphological species resolved among 68 isolates associated with root rot disease symptoms. Of the various loci screened, nrRNA-ITS sequences were the least informative, while histone H3 sequences were the most informative, resolving the same number of species as the combined dataset across the four genes. Within the Ilyonectria radicicola species complex, 12 new taxa are delineated occurring on a diverse range of
\end{abstract}

\author{
A. Cabral $\cdot$ C. Rego $\cdot$ H. Oliveira $(\square)$ \\ CEER-Biosystems Engineering, Instituto Superior de Agronomia, \\ Technical University of Lisbon, \\ Tapada da Ajuda, \\ 1349-017 Lisboa, Portugal \\ e-mail: heloliveira@isa.utl.pt \\ J. Z. Groenewald • P. W. Crous \\ CBS-KNAW Fungal Biodiversity Centre, \\ P.O. Box 85167, 3508 AD Utrecht, The Netherlands
}

\section{P. W. Crous}

Microbiology, Department of Biology, Utrecht University,

Padualaan 8 ,

$3584 \mathrm{CH}$ Utrecht, The Netherlands

\section{P. W. Crous}

Laboratory of Phytopathology,

Wageningen University and Research Centre (WUR),

Droevendaalsesteeg 1 ,

6708 PB Wageningen, The Netherlands hosts, the most common being Cyclamen, Lilium, Panax, Pseudotsuga, Quercus and Vitis.

Keywords Cylindrocarpon root rot - Nectria-like fungi . Phylogeny· Systematics

\section{Introduction}

The genus Cylindrocarpon was introduced in 1913 by Wollenweber, with C. cylindroides as type. Cylindrocarpon and Cylindrocarpon-like species have since been commonly associated with root and decay of woody and herbaceous plants (Domsch et al. 2007). Cylindrocarpon root rot causes losses up to $30 \%$ on ginseng (Panax quinquefolium) (Seifert et al. 2003), and plays an important role in black foot rot of grapevines (Halleen et al. 2004, 2006), apple replant disease (Tewoldemedhin et al. 2010), and beech cankers (Castlebury et al. 2006), to name but a few hosts of economic importance.

In his taxonomic revision of Cylindrocarpon, Booth (1966) divided this genus into four groups based on the presence or absence of microconidia or chlamydospores. Booth's group 4 represents Neonectria s. str., as it accommodates the type species $N$. ramulariae (anamorph: $C$. obtusiusculum). Most of the teleomorphs of Cylindrocarpon species have since this date been classified in Neonectria (Brayford et al. 2004; Halleen et al. 2004, 2006; Mantiri et al. 2001; Rossman et al. 1999). Several phylogenetic studies have, however, revealed that Neonectria/Cylindrocarpon is paraphyletic (Castlebury et al. 2006; Halleen et al. 2004, 2006; Hirooka et al. 2005; Mantiri et al. 2001). The first step in resolving this issue was taken by Halleen et al. (2004), who proposed Campylocarpon for species resembling Cylindrocarpon with 3-5-septate, curved macroconidia, and 
lacking microconidia. A further phylogenetic study (Chaverri et al. 2011) divided the Neonectria complex into four genera based on a combination of characters linked to perithecial anatomy and conidial septation: Ilyonectria, Neonectria/ Cylindrocarpon s. str., Rugonectria and Thelonectria. In this study, a single generic name was proposed for each clade in an attempt to move towards a single nomenclature for pleomorphic fungi, meaning that the Cylindrocarpon-like anamorphs of Ilyonectria, Rugonectria and Thelonectria were placed in teleomorph genera, as recently done with other groups of pleomorphic fungi (Crous et al. 2006, 2007, 2009a; Gräfenhan et al. 2011; Lombard et al. 2010; Schroers et al. 2011).

Cylindrocarpon root rot is commonly associated with "Cylindrocarpon" destructans in the literature (Halleen et al. 2004; Samuels and Brayford 1990). This fungus was originally described as Ramularia destructans from roots of ginseng (Panax quinquefolium) collected in the USA (Zinssmeister 1918). Furthermore, it has been linked to the teleomorph Ilyonectria radicicola (Booth 1966; Chaverri et al. 2011; Samuels and Brayford 1990), which Gerlach and Nilsson (1963) described from rotting bulbs of Cyclamen persicum collected in Sweden. Samuels and Brayford (1990) commented on the morphological variation in collections of I. radicicola and its anamorph "C." destructans. Seifert et al. (2003) showed that there was more than one " $C$." destructans-like species occurring on Panax, and that none of the resolved clades correlated to the ex-type strain of $I$. radicicola, leading Halleen et al. (2006) to question the purported anamorph/teleomorph link between I. radicicola (from Cyclamen, Sweden) and "C." destructans (from Panax, USA). Based on a phylogenetic analysis of ITS nrRNA gene sequences, Schroers et al. (2008) concluded that the I. radicicola complex includes " $C$." destructans, "C." destructans var crassum, I. coprosmae, I. liriodendri, $N$. austroradicicola and N. macroconidialis.

The aim of the present study was to elucidate the morphological variation present within the $I$. radicicola complex, and to link fresh collections to older names introduced for species in this complex. This was addressed by combining morphological and culture characteristics with DNA sequence data derived from the Internal Transcribed Spacers (ITS) of the nrRNA gene operon, and partial $\beta$-tubulin (TUB), histone H3 (HIS), and translation elongation factor $1-\alpha$ (TEF) genes.

\section{Materials and methods}

Isolates

This study (Table 1) included 42 "C." destructans s. lat. isolates [including the ex-type strains of I. radicicola (CBS
264.65) and "C." destructans f.sp. panacis (CBS 124662), " $C$." destructans var. destructans and " $C$." destructans var. crassum], six " $C$." didymum isolates, six I. liriodendri isolates, one $N$. macroconidialis isolate and one I. coprosmae isolate, all deposited at the CBS-KNAW Fungal Biodiversity Centre, Utrecht, the Netherlands (CBS). Also included are two isolates that were previously identified as Ramularia mors-panacis (CBS 306.35) and $R$. panacicola (CBS 307.35) by Hildebrand (1935).

Besides those, 10 "Cylindrocarpon" spp. isolates were obtained in Portugal from grapevine plants showing decline symptoms, either 1- to 6-year-old plants in vineyards (Cy22, Cy155, Cy158, Cy190, CBS 129078, CBS 129080, CBS 129081, CBS 129082) or from rootstock nurseries (Cy23), and from a 25-year-old grapevine plant with esca symptoms (CBS 129084). Furthermore, isolates were obtained from a young Malus domestica (Cy164) and from the stem of a young Quercus suber (Cy232) plant, both showing decline symptoms, and from Thymus sp. (Cy231) and Ficus sp. (Cy228). One isolate (Cy131) was made available by P. Lecomte (Institut National de la Recherche Agronomique, Bordeaux-Aquitaine, France) and was obtained from an internal lesion of a stem of Actinidia chinensis 'Hayward'. Another isolate (Cy122) was made available by W.D. Gubler (University of California, Davis, USA) and was obtained from Vitis sp. All of these isolates are stored in a culture collection at the Laboratório de Patologia Vegetal "Veríssimo de Almeida" (LPVVA-ISA, Lisbon, Portugal).

An additional 25 "C." destructans isolates used during this study were made available by K.A. Seifert (Agriculture and Agri-Food, Canada), and were isolated from commercial Panax quinquefolium gardens (CBS 120359-120369, CBS 129079, CBS 129083, CD1666, CPC 13535, CPC 13537, NSAC-SH2, NSAC-SH2.5), Picea glauca (94-1628, CPC 13539), Poa pratensis (CPC 13534), Pseudotsuga menziesii (CBS 120370-120372, CPC 13536) and Prunus cerasus (CPC 13532) (Seifert et al. 2003).

Another 109 isolates were also included in the analysis to add phylogenetic support to this study and represent strains of the following taxa: C. cylindroides, C. obtusisporum, $C$. pauciseptatum, species 1 to 6 (Mostert et al., in preparation; Cabral et al., in preparation), I. macrodidyma, N. ditissima, $N$. major, $N$. neomacrospora and $N$. ramulariae.

DNA isolation, sequencing and phylogenetic analysis

For each isolate, genomic DNA was isolated from mycelium following the protocol of Möller et al. (1992), adapted by Crous et al. (2009b). Sequencing of the ITS and part of the $\beta$-tubulin (TUB), histone H3 (HIS) and translation elongation factor $1-\alpha$ (TEF) genes was performed after PCR amplification using $1 \times$ PCR buffer (Bioline, London, 


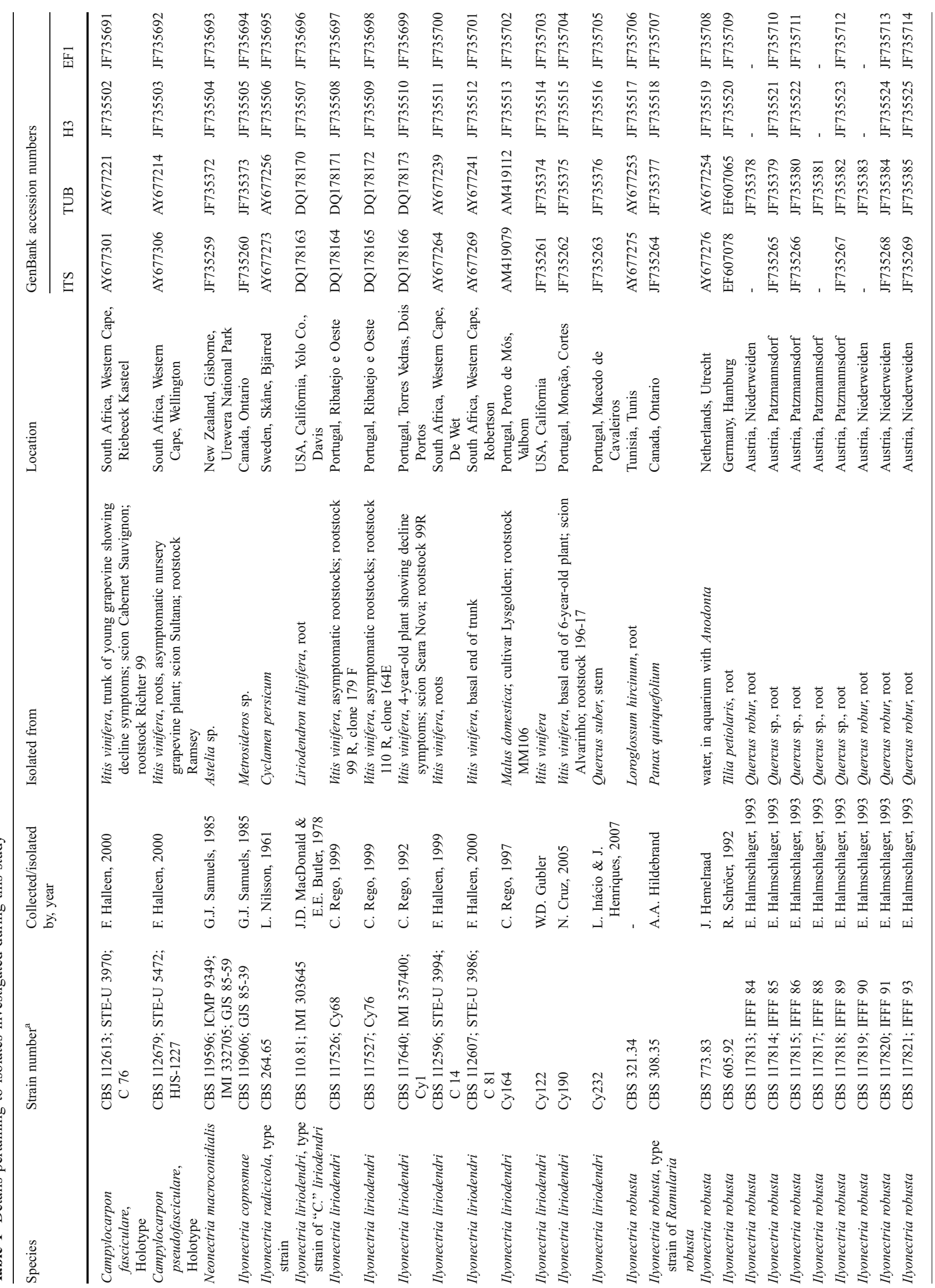




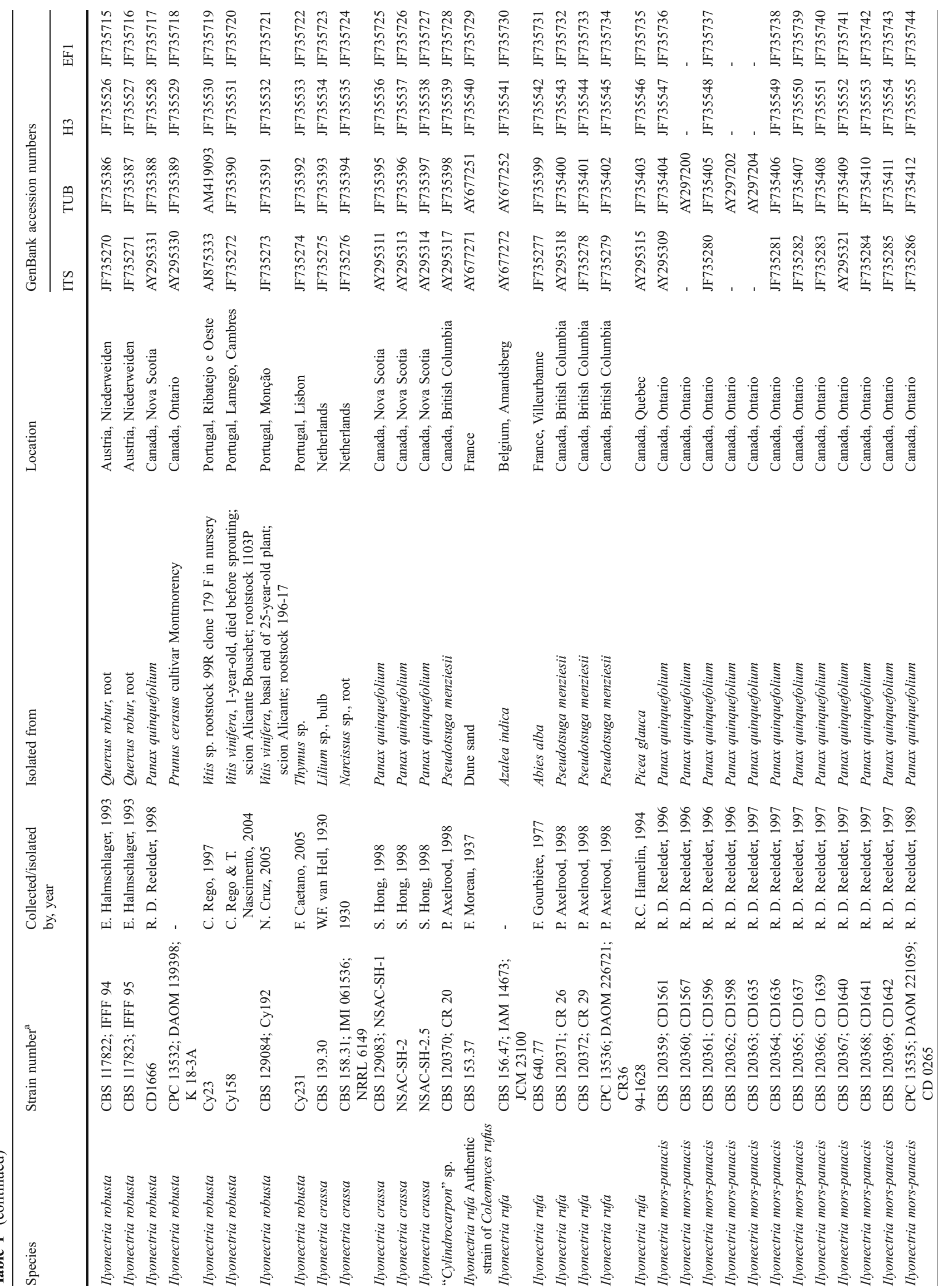




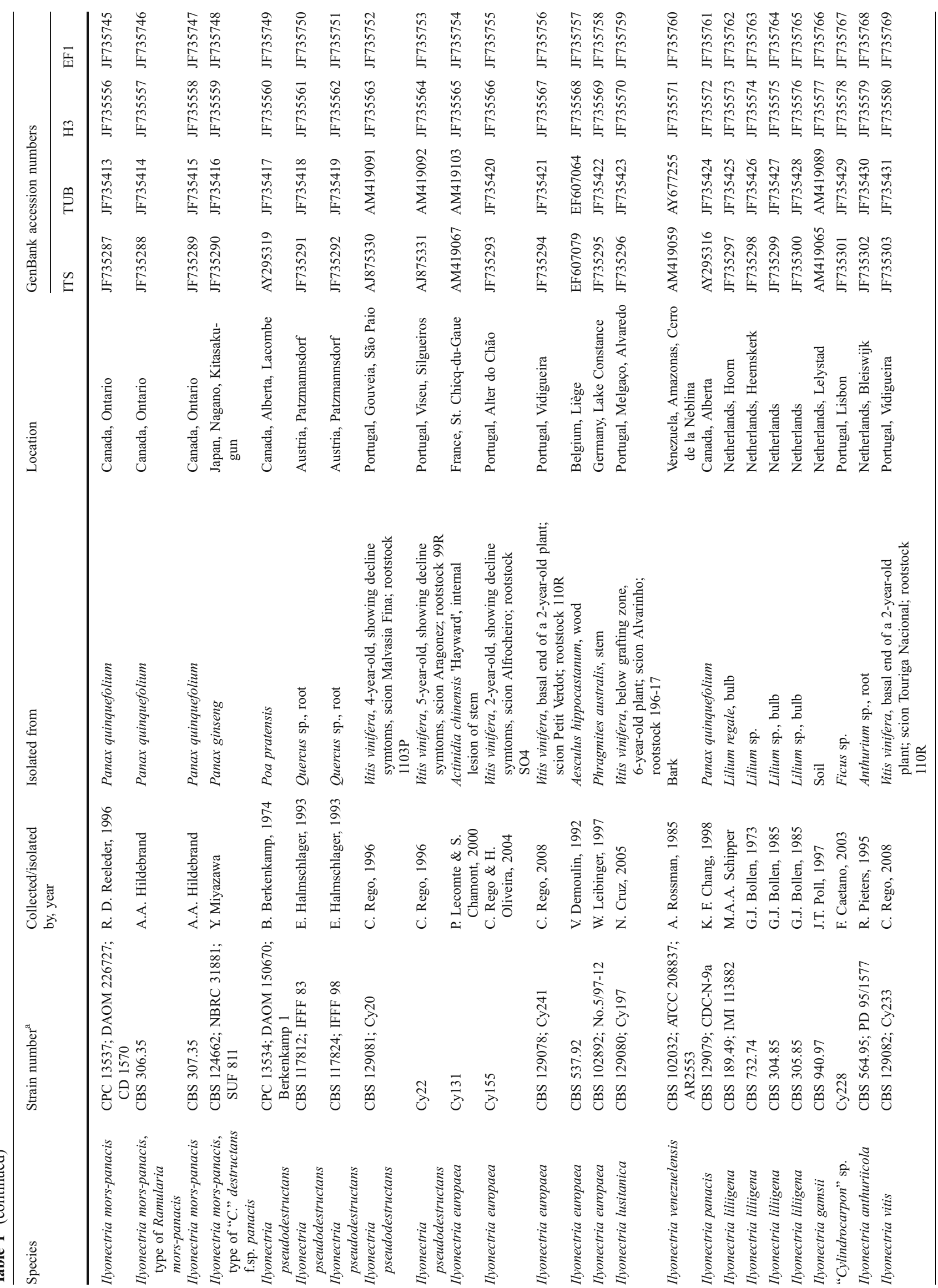




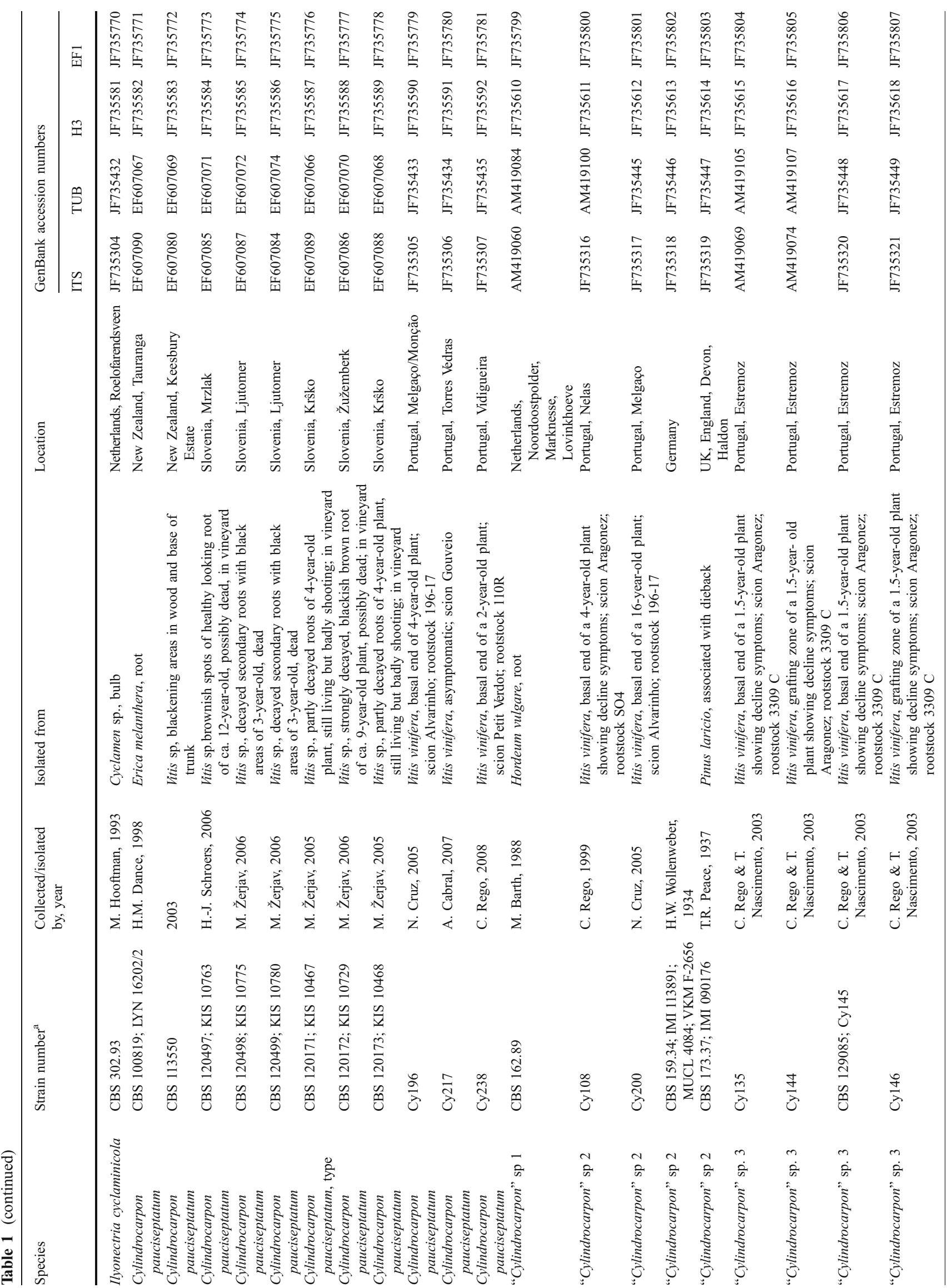




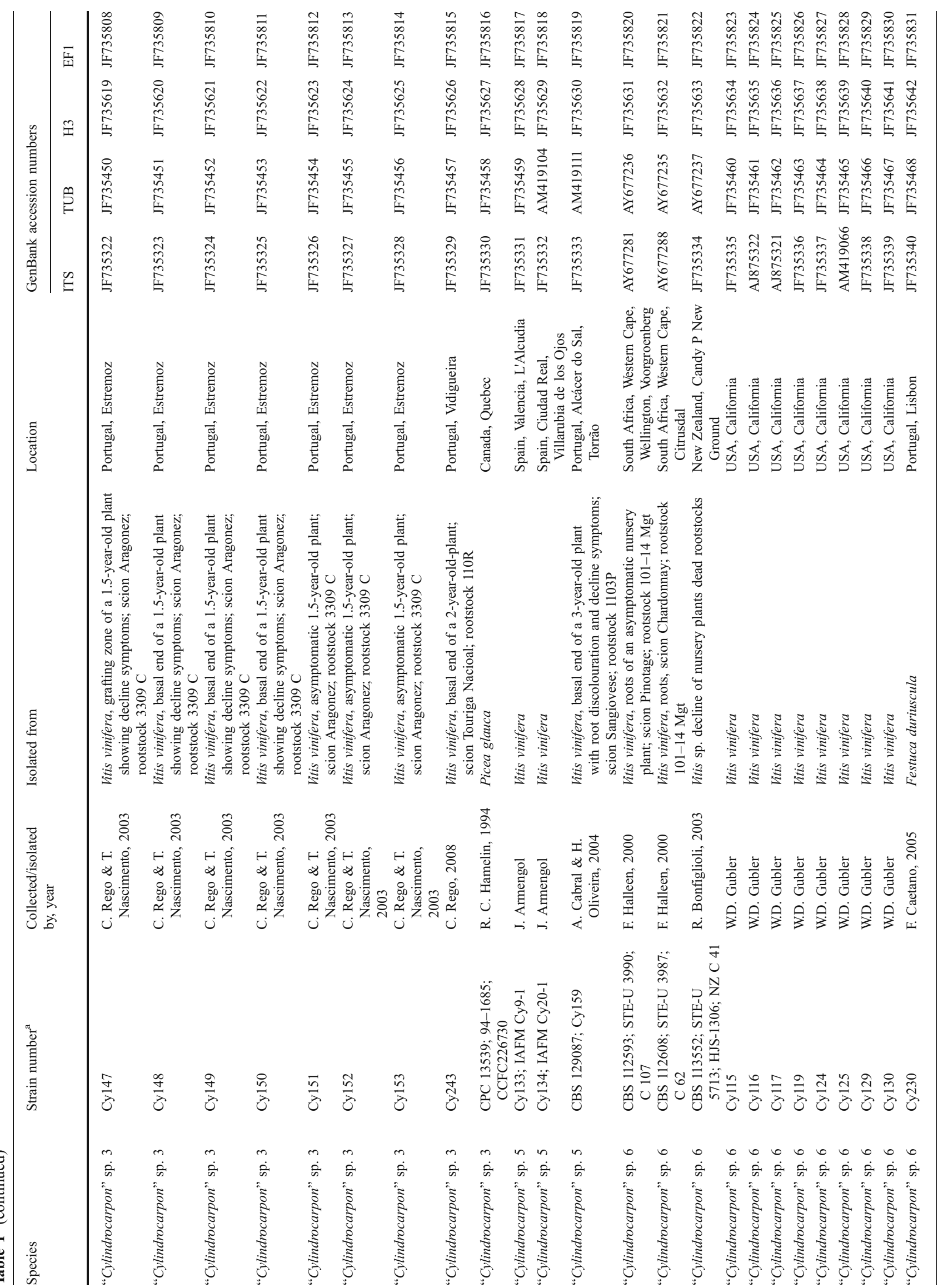




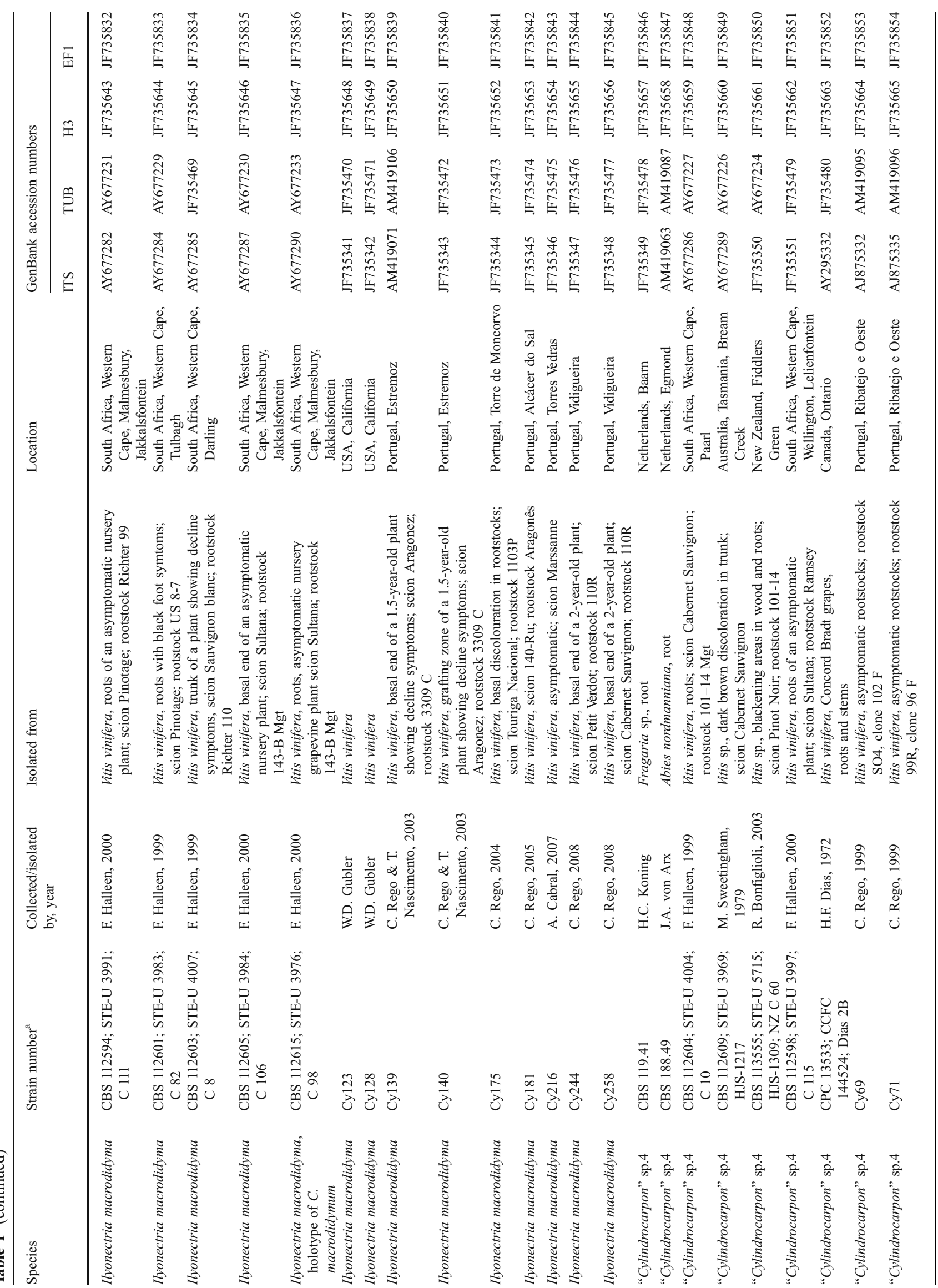




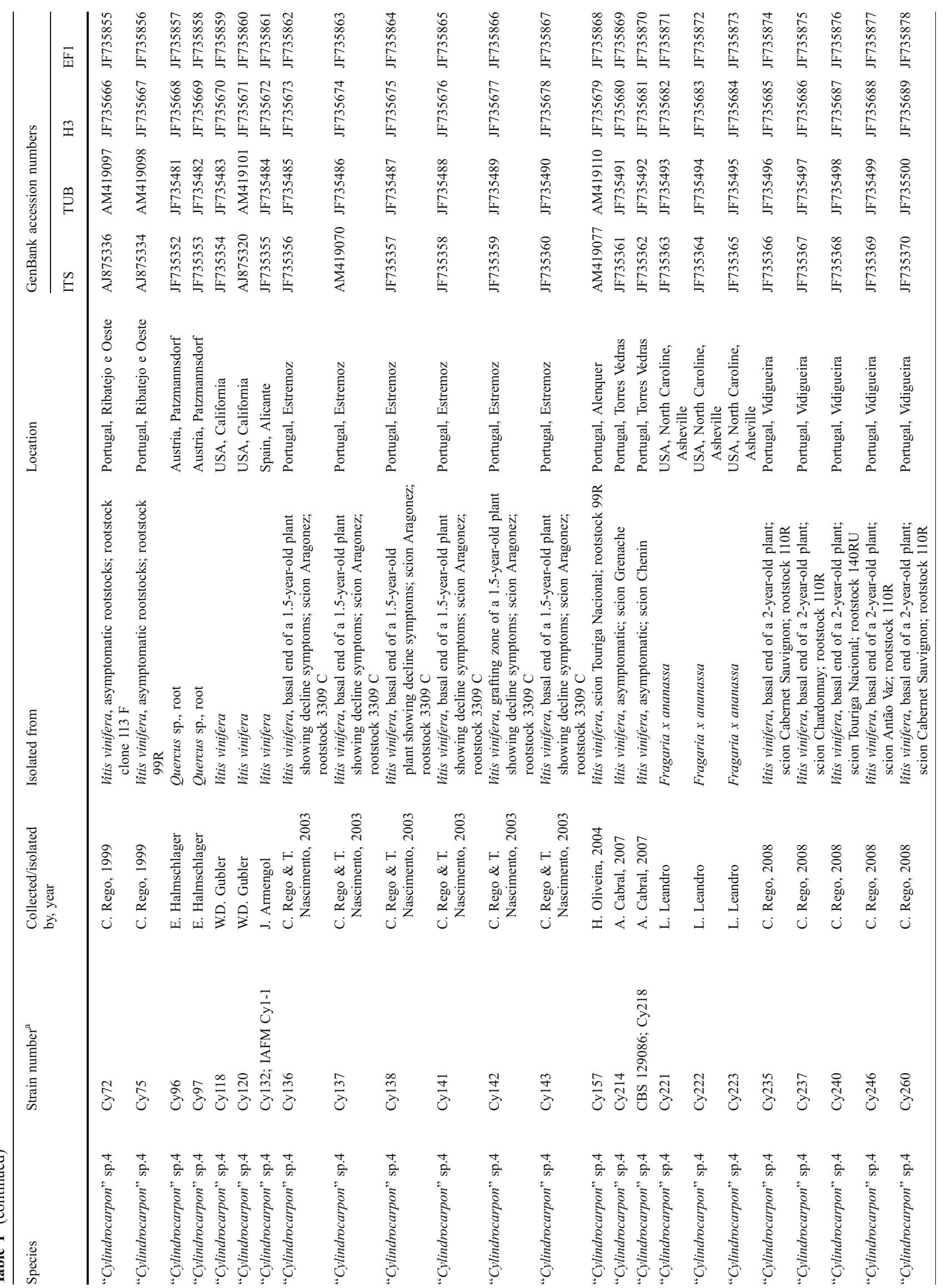




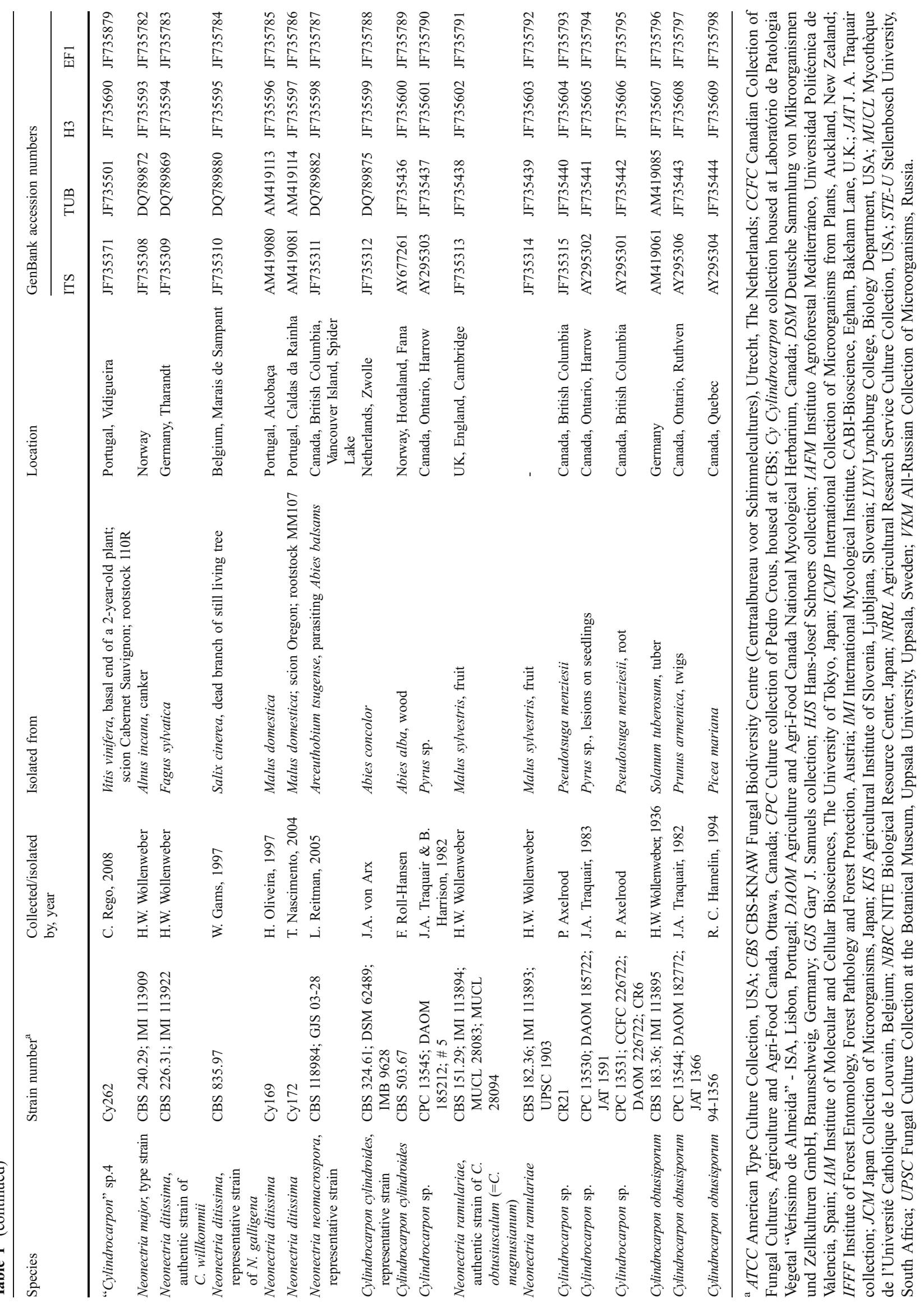


UK), $1.5 \mathrm{mM} \mathrm{MgCl} 2,32 \mu \mathrm{M}$ of each dNTPs, $0.24 \mu \mathrm{M}$ of each primer, 0.5 units Taq DNA Polymerase (Bioline), and $1 \mu \mathrm{l}$ of diluted gDNA in a final volume of $12.5 \mu \mathrm{l}$. The cycle conditions in a iCycler thermocycler (BioRad, Hercules, USA) were $94^{\circ} \mathrm{C}$ for $5 \mathrm{~min}$, followed by 40 cycles at $94^{\circ} \mathrm{C}$ for $30 \mathrm{~s}, 52^{\circ} \mathrm{C}$ for $30 \mathrm{~s}$ and $72^{\circ} \mathrm{C}$ for $80 \mathrm{~s}$, and a final elongation at $72^{\circ} \mathrm{C}$ for $10 \mathrm{~min}$. Primers were V9G (de Hoog and Gerrits van den Ende 1998) and ITS4 (White et al. 1990) for ITS, T1 (O'Donnell and Cigelnik 1997) and Bt-2b (Glass and Donaldson 1995) for TUB, CYLH3F and CYLH3R (Crous et al. 2004b) for HIS, and EF1 and EF2 (O'Donnell et al. 1998) or CylEF-1 (5'- ATG GGT AAG GAV GAV AAG AC-3'; J.Z. Groenewald, unpublished) and CylEF-R2 (Crous et al. 2004b) for TEF. For TEF, the following modifications were made to the amplification protocol: $2.0 \mathrm{mM}$ of $\mathrm{MgCl}_{2}, 40 \mu \mathrm{M}$ of each dNTPs and addition of 5\% of Dimethyl sulfoxide (DMSO; Sigma-Aldrich, Zwijndrecht, Netherlands).

After confirmation by agarose gel electrophoresis, amplicons were sequenced in both directions with the corresponding PCR primers and a DYEnamic ET Terminator Cycle Sequencing Kit (Amersham Biosciences, Diegem, Belgium) according to the manufacturer's recommendations. The products were analysed on an ABI Prism 3700 DNA Sequencer (Perkin-Elmer, Waltham, USA).

Sequences were assembled and edited to resolve ambiguities, using the EditSeq and SeqMan modules of the Lasergene software package (DNAStar, Madison, USA). Consensus sequences for all isolates were compiled into a single file (Fasta format) and aligned using CLUSTAL X v. 2.0.11 (Larkin et al. 2007). Following manual adjustment of the alignment by eye where necessary, the alignment was subjected to phylogenetic analyses as described by Crous et al. (2004b). Novel sequences were lodged in GenBank (Table 1), taxonomic novelties in MycoBank (Crous et al. 2004a), and the alignments and phylogenetic trees in TreeBASE (http://www.treebase.org).

\section{Morphology}

Isolates were grown for up to 5 weeks at $20^{\circ} \mathrm{C}$ on synthetic nutrient poor agar (SNA; Nirenberg 1976) with and without two $1-\mathrm{cm}^{2}$ filter paper pieces, carnation leaf agar (CLA; Crous et al. 2009b), potato-dextrose agar (PDA; Difco, Detroit, USA) and oatmeal agar (OA; Crous et al. 2009b) under continuous n-UV light (NUV, 400-315 nm; Blacklight-Blue; Sylvania, Capelle a/d Ijssel, Netherlands).

Measurements were done on a $1-\mathrm{cm}^{2}$ agar plug removed from the colony margin, placed on a microscope slide, to which a drop of water and coverslip were added. For each isolate, 30 measurements were obtained for each structure. Measurements were done at $\times 1,000$ magnification using a Nikon Eclipse 80i microscope, or a Leica DM2500. Images were captured using a Nikon DS-Fil digital camera with NIS-Elements Software, or a Leica DFC295 digital camera with the Leica Application Suite. Measurements for length and width of conidia and ascospores are given as (Minimum) Lower Limit of a 95\% Confidence Interval Upper Limit of a 95\% Confidence Interval (Maximum). For other measurements, only the extreme values are given.

Culture characteristics (texture, density, colour, growth front, transparency and zonation) were described on PDA after incubation at $20^{\circ} \mathrm{C}$ in the dark for 14 days. Colour (surface and reverse) was described using the colour chart of Rayner (1970). Cardinal temperatures for growth were assessed by inoculating 90-mm-diam PDA dishes with a 3mm-diam plug cut from the edge of an actively growing colony. Growth was determined after 7 days in two orthogonal directions. Trials were conducted at various temperatures $\left(4,10,15,18,20,22,25,30\right.$ and $\left.35^{\circ} \mathrm{C}\right)$ with three replicate plates per strain at each temperature.

To induce the formation of perithecia, isolates were crossed in 60-mm-diam Petri dishes containing a minimal salts medium supplemented with two sterile birch toothpicks (Guerber and Correll 2001). The plates were incubated at $20^{\circ} \mathrm{C}$ under n-UV light for $8-20$ weeks. Two strains were considered sexually compatible if perithecia were formed that exuded masses of viable ascospores. The colour reaction of the perithecia was checked in $3 \% \mathrm{KOH}$ and in lactic acid. For sectioning, perithecia were mounted in Jung Tissue Freezing Medium (Leica) or in Arabian Gum, and cut in 10 - to $15-\mu \mathrm{m}$-thick sections using a Leica cryostat $\mathrm{CM} 3050 \mathrm{~S}$ or $\mathrm{CM} 1850$ at $-20^{\circ} \mathrm{C}$.

\section{Results}

Phylogeny

Amplification products of approximately 700 bases (ITS), 650 bases (TUB), 500 bases (HIS) and $600-800$ bases (TEF) were obtained for the isolates listed in Table 1. The manually adjusted combined alignment contains 189 sequences (including the two outgroup sequences) and the statistical parameters for the combined and individual analyses are presented in Table 2. For the combined analysis, only a maximum of 1,000 equally most parsimonious trees were saved, the first of which is presented as Fig. 1. Phylogenetic trees derived from the individual loci are available in TreeBASE. The combined analysis of the four genes enabled the identification of 37 species. However, the analysis of HIS data alone was enough to resolve these taxa. Sequences of TEF could not distinguish species 6, I. robusta, I. europaea, I. lusitanica, I. rufa and $N$. ditissima; whereas sequences of TUB could not separate I. robusta, species 4, and 6, while "I." macro- 
Table 2 Statistical information on the individual datasets and number of equally most parsimonious trees for each locus [Internal Transcribed Spacers (ITS) of the nuclear ribosomal RNA gene operon, and partial $\beta$-tubulin $(T U B)$, histone $\mathrm{H} 3(H I S)$ and translation elongation factor $1-\alpha(T E F)$ genes]

\begin{tabular}{|c|c|c|c|c|c|}
\hline & ITS & TUB & HIS & TEF & Combined \\
\hline Aligned characters (including gaps) & 475 & 502 & 440 & 696 & 2,113 \\
\hline Parsimony-informative characters & 122 & 212 & 215 & 364 & 913 \\
\hline Variable and parsimony-uninformative characters & 31 & 38 & 11 & 43 & 123 \\
\hline Constant characters & 322 & 252 & 214 & 289 & 1,077 \\
\hline Equally most parsimonious trees obtained & 136 & 384 & 1 & 60 & 1,000 \\
\hline Tree length & 294 & 603 & 1,095 & 1,149 & 3,259 \\
\hline Consistency index $(\mathrm{Cl})$ & 0.718 & 0.660 & 0.468 & 0.611 & 0.559 \\
\hline Retention index (RI) & 0.978 & 0.972 & 0.946 & 0.966 & 0.959 \\
\hline Rescaled Consistency index (RC) & 0.702 & 0.642 & 0.442 & 0.590 & 0.537 \\
\hline
\end{tabular}

didyma, species 5, I. liliigena and I. pseudodesctructans were supported by low bootstrap values, and CBS 120370 clustered apart from the remaining isolates of I. crassa. Of all loci screened, ITS proved to be the least informative, being unable to resolve 22 of the species in this study. Neighbour-Joining (NJ) analyses using the three substitution models, as well as the parsimony analysis, yielded trees with similar topology and bootstrap support values for the individual and combined gene analyses. The trees obtained supported the same clades, sometimes with rearrangements in the order of these clades between the different analyses (data not shown). The results of the phylogenetic analyses are highlighted below under the taxonomic notes or in the Discussion, where applicable.

\section{Taxonomy}

The present study treats isolates that have been freshly collected, or previously identified and maintained in culture collections as "Cylindrocarpon destructans", meaning cylindrical, rarely curved, 3-septate macroconidia with obtuse apices, abundant microconidia and chlamydospores (Samuels and Brayford 1990). The latter species has in the past been acknowledged as anamorph of I. radicicola (Booth 1966; Chaverri et al. 2011; Samuels and Brayford 1990). However, an examination of the neotype of " $C$." destructans in this study [CUP-011985, conidia (18.0)23.0$30.0(35.0) \times(6.0) 6.5(7.0) \mu \mathrm{m}]$, found conidia to be considerably smaller than those of $I$. radicicola (24.0)33.1 $(47.0) \times(4.9) 6.4(7.8) \mu \mathrm{m}$ (Gerlach and Nilsson 1963) (also confirmed in the present study by examination of CBS 264.65, ex-type), revealing them to represent two distinct species. Furthermore, based on the phylogenetic and morphological data obtained in the present study, several novel species could be distinguished that are phylogenetically distinct from $I$. radicicola, and morphologically distinct based on a range of characters linked to culture characteristics, conidiophores, macro- and microconidium morphology. Some of these could be linked to older names, or taxa long regarded as potential syonyms of "destructans", which could now be resurrected. These taxa are treated below:

Ilyonectria anthuriicola A. Cabral \& Crous, sp. nov. (Fig. 2)

MycoBank 560108.

Etymology: Named after its host, Anthurium.

Cylindrocarpi destructantis morphologice simile, sed longitudine media conidiorum longiore, 29.5-32.2 $\mu \mathrm{m}$, distinguitur.

Conidiophores simple or complex to sporodochial. Simple conidiophores arising laterally or terminally from aerial mycelium, solitary to loosely aggregated, unbranched or sparsely branched bearing up to three phialides, 1-3septate, 40-95 $\mu \mathrm{m}$ long; phialides monophialidic, more or less cylindrical but slightly tapering towards the tip, 10.5$20.5 \mu \mathrm{m}$ long, $2.5-3.5 \mu \mathrm{m}$ wide at the base, $3.0-4.5 \mu \mathrm{m}$ at widest point, $1.5-2.5 \mu \mathrm{m}$ near the aperture. Conidiophores giving rise to microconidia, formed on mycelium at agar surface, penicillately mono- or bi-verticillate; phialides monophialidic, narrowly flask-shaped, typically with widest point near the middle, 8-15 $\mu \mathrm{m}$ long, 2.0-3.0 $\mu \mathrm{m}$ wide at the base, 2.5-4.5 $\mu \mathrm{m}$ at widest point, 1.0-2.0 $\mu \mathrm{m}$ near the apex. Sporodochial conidiophores irregularly branched; phialides cylindrical, mostly widest near the middle. Macroconidia formed in flat domes of slimy masses, (1-)

Fig. 1 The first of 1,000 equally most parsimonious trees obtained from the combined ITS, TUB, HIS and TEF sequence alignment of Cylindrocarpon isolates and relatives with a heuristic search using PAUP v. 4.0b10. The tree was rooted using Campylocarpon isolates as outgroup sequences and bootstrap support values are indicated near the nodes, where"ns" designates not supported. Ex-type strains are indicated in bold. Newly described species are indicated by blue boxes. Scale bar shows 10 changes 
CBS 112613 Vitis, South Afric

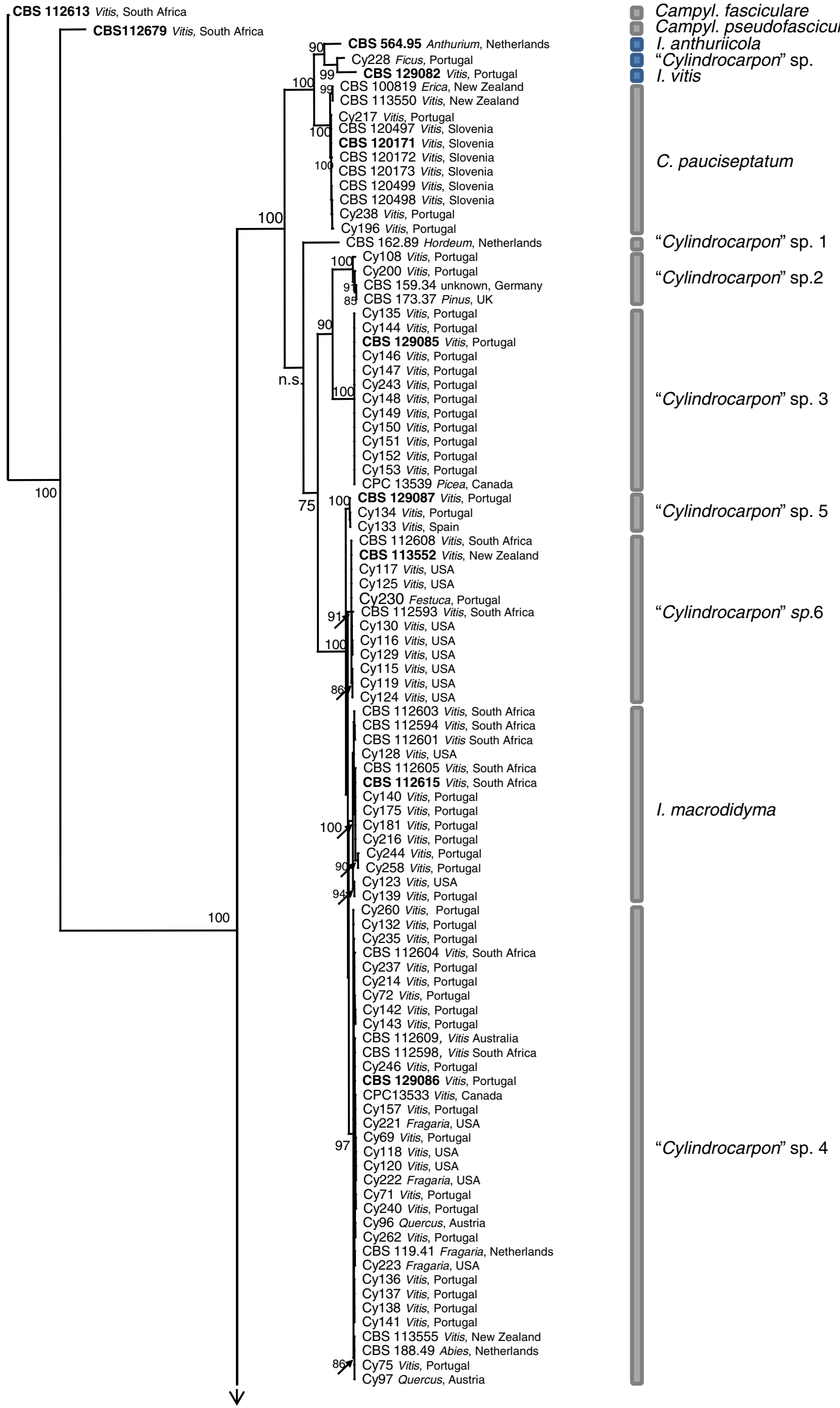


Fig. 1 (continued)

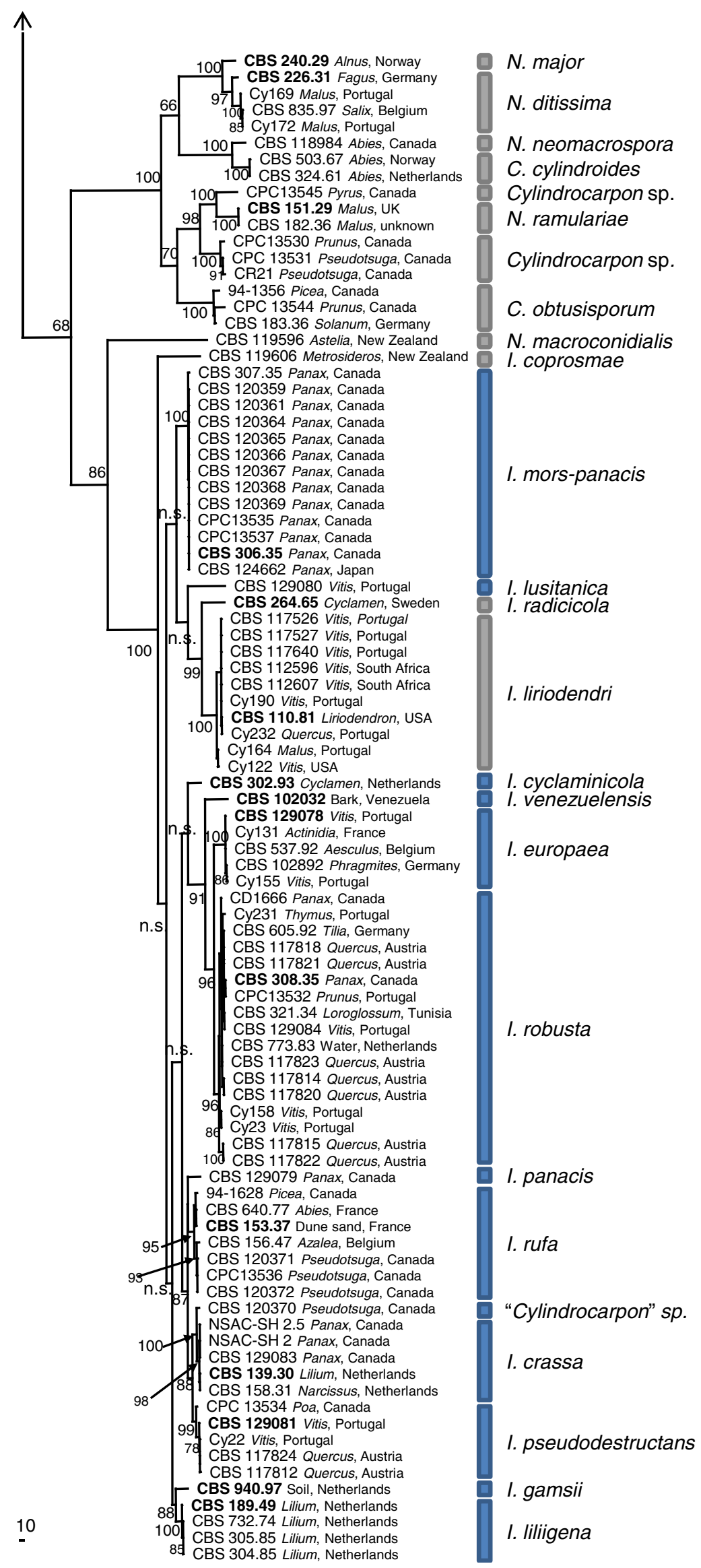



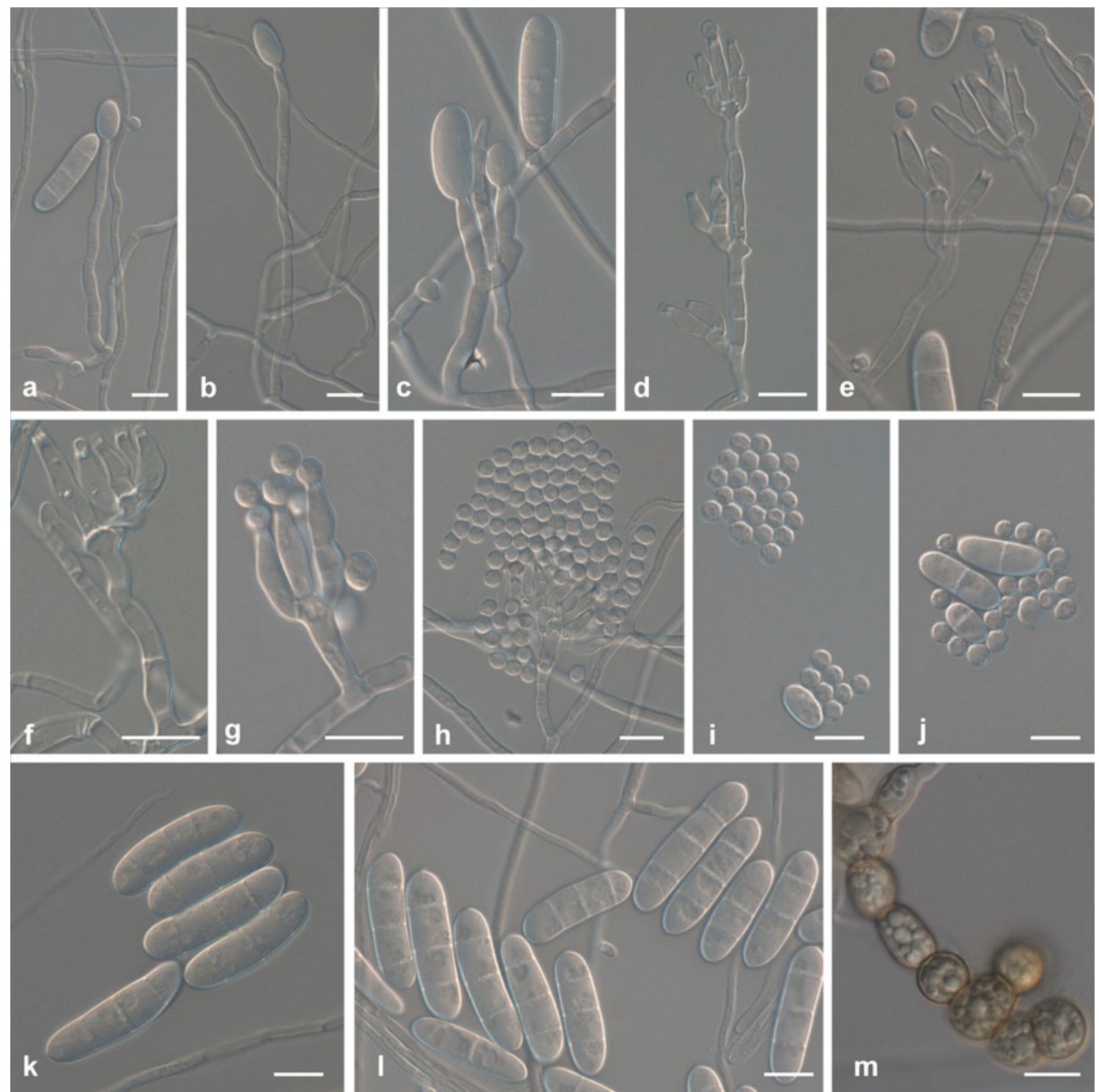

Fig. 2 Ilyonectria anthuriicola (CBS 564.95). a-c Simple conidiophores on aerial mycelium. $\mathbf{d}-\mathbf{g}$ Conidiophores giving rise to microconidia, formed on mycelium at agar surface, penicillately mono- or

3-septate, straight or minutely curved, cylindrical with both ends more or less obtusely rounded, mostly without a visible hilum; 1-septate, (20.0)23.5-26.7(29.0)×(5.5)5.9$6.8(7.0) \mu \mathrm{m}$ (average $=25.1 \times 6.4 \mu \mathrm{m})$, with a length:width ratio of 3.6-4.8; 2-septate, (25.0)26.6-29.3(32.0) $\times(6.5)$ $6.8-7.8(8.5) \mu \mathrm{m}(\mathrm{av} .=27.9 \times 7.3 \mu \mathrm{m})$, with a length:width ratio of 3.2-4.8; 3-septate, (25.0)29.5-32.2(38.0) $\times(6.0)$ $7.5-8.1(9.0) \mu \mathrm{m}(\mathrm{av} .=30.8 \times 7.8 \mu \mathrm{m})$ with a length:width ratio of 3.1-5.2. Microconidia $0(-1)$-septate, subglobose to ovoid, rarely ellipsoid, mostly with a visible centrally located or slightly laterally displaced hilum; aseptate microconidia, (4.9)5.0-8.1(12.0) $\times(4.0) 4.3-5.5(6.5) \mu \mathrm{m}$ (av. $=6.5 \times 4.9 \mu \mathrm{m}$ ), with a length:width ratio of $1.0-1.8$; 1-septate, (11.0)11.6-16.7(18.0)×(5.0)5.4-6.1(6.0) $\mu \mathrm{m}$ bi-verticillate. h-l Micro- and macroconidia. m Chlamydospores in mycelium. Bars $10 \mu \mathrm{m}$

$(\mathrm{av} .=14.1 \times 5.8 \mu \mathrm{m})$, with a length:width ratio $1.8-3.0$. Chlamydospores globose to subglobose to ellipsoid, 8$14 \times 7-12 \mu \mathrm{m}$, smooth, but often appearing rough due to deposits, thick-walled, formed intercalary in chains or in clumps and also in the cells of macroconidia, hyaline, becoming golden-brown.

Holotype: Netherlands, Bleiswijk, root rot of Anthurium sp., 1995, coll./isol. R. Pieters, holotype CBS H-20555, culture ex-type CBS 564.95.

Culture characteristics: Mycelium felty with average density. Surface on OA chestnut, with aerial mycelium sparse, saffron; margin pure yellow to orange. Surface on PDA, chestnut with saffron aerial mycelium, growth at margin luteous; zonation absent, transparency homogeneous, margin 
even; reverse similar to surface, but chestnut to cinnamon on $\mathrm{OA}$, and chestnut on PDA. Colonies on PDA do not grow at $4^{\circ} \mathrm{C}$ after 7 days. Optimum temperature $20^{\circ} \mathrm{C}$ when colonies reach 25-27 mm, after 7 days. Colony diam was 20-22 $\mathrm{mm}$ at $25^{\circ} \mathrm{C}$, after 7 days. Hardly grows at $30^{\circ} \mathrm{C}(2 \mathrm{~mm}$ colony diam after 7 days).

Isolate studied: CBS 564.95 (Table 1).

Host and distribution: Roots of Anthurium sp. (Netherlands).

Ilyonectria crassa (Wollenw.) A. Cabral \& Crous, comb. et stat. nov. (Fig. 3)

\section{MycoBank 560109.}

Basionym: Cylindrocarpon radicicola var. crassum Wollenw., Z. Parasitenkunde 3: 495. 1931.

$\equiv$ Cylindrocarpon destructans var crassum (Wollenw.) C. Booth, Mycol. Pap. 104: 37. 1966.

Conidiophores simple or complex, to sporodochial. Simple conidiophores arising laterally or terminally from aerial mycelium, solitary to loosely aggregated, unbranched or sparsely branched bearing up to two phialides, rarely consisting only of phialides, 1-4-septate, 40-180 $\mu \mathrm{m}$ long; phialides monophialidic, cylindrical to subulate, $20-55 \mu \mathrm{m}$ long, 2.5-4.0 $\mu \mathrm{m}$ wide at the base, 1.5-2.0 $\mu \mathrm{m}$ near the apex. Complex conidiophores aggregated in small sporodochia (on carnation leaf), repeatedly and irregularly branched; phialides more or less cylindrical, but tapering slightly in the upper part towards the apex, or narrowly flask-shaped, mostly with widest point near the middle, 17$24 \mu \mathrm{m}$ long, 2.0-3.0 $\mu \mathrm{m}$ wide at the base, 2.5-3.5 $\mu \mathrm{m}$ at the widest point, and 1.5-2.5 $\mu \mathrm{m}$ wide near the apex. Macroconidia predominating, formed on both type of conidiophores, on SNA formed in flat domes of slimy masses, 1-3-septate, straight, cylindrical, but may narrow towards the tip, more or less broadly rounded, and the base appearing somewhat acute due to the presence of the hilum, mostly centrally located; 1-septate, (21.0)25.7-27.3(34.0) $\times$ (4.5)5.0-5.3(6.5) $\mu \mathrm{m}(\mathrm{av} .=26.5 \times 5.1 \mu \mathrm{m})$, with a length: width ratio of $3.8-6.7$; 2-septate, (23.0)28.5-30.3(37.0) $\times$ (4.5)5.3-5.6(6.5) $\mu \mathrm{m}$ (av. $=29.4 \times 5.4 \mu \mathrm{m})$ with a length: width ratio of 4.2-6.7; 3-septate, (29.0)34.1-36.0(49.0) $\times$ (5.0)5.6-5.8(7.0) $\mu \mathrm{m}(\mathrm{av} .=35.1 \times 5.7 \mu \mathrm{m})$, with a length: width ratio of 4.8-8.9. Microconidia $0-1$-septate, ellipsoid to subcylindrical, more or less straight, with a visible, truncate hilum; aseptate microconidia, (7.0)9.7-10.9 $(15.0) \times(3.0) 3.3-3.6(4.5) \mu \mathrm{m}(\mathrm{av} .=10.3 \times 3.5 \mu \mathrm{m})$, with a length:width ratio of $1.8-4.3 ; 1$-septate, (12.0)14.2-15.2 $(19.0) \times(3.0) 3.8-4.2(5.0) \mu \mathrm{m}(\mathrm{av} .=14.7 \times 4.0 \mu \mathrm{m})$, with a length:width ratio 2.7-5.0. Conidia formed in heads on simple conidiophores or as white (OA) or unpigmented (SNA) masses. Chlamydospores globose to subglobose to cylindrical, 7-15×6-10 $\mu \mathrm{m}$, smooth, but often appearing rough due to deposits, thick-walled, terminal on short
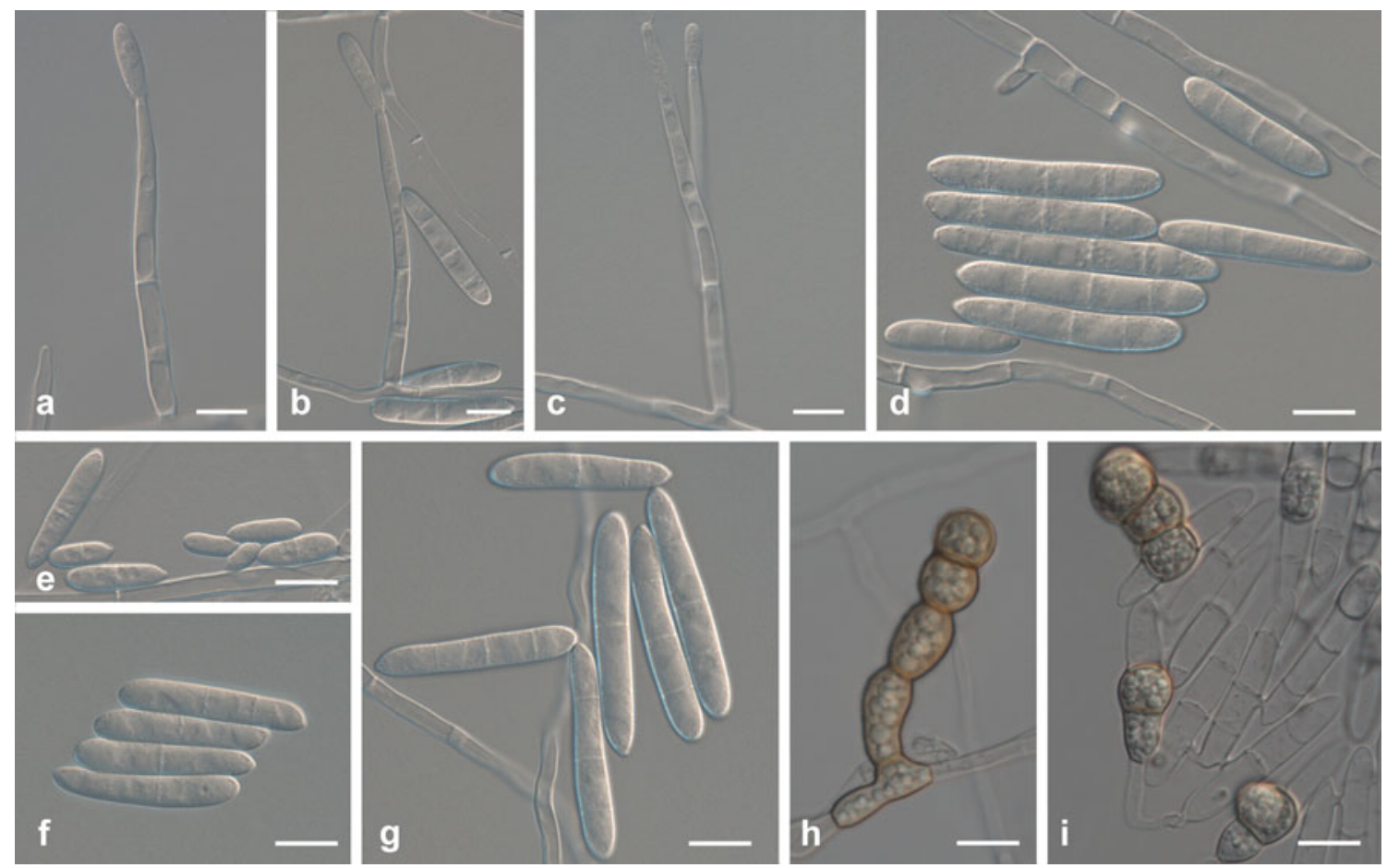

Fig. 3 Ilyonectria crassa (CBS 129083). a-c Simple conidiophores on aerial mycelium. $\mathbf{d}-\mathbf{g}$ Micro- and macroconidia. $\mathbf{h}-\mathbf{i}$ Chlamydospores and macroconidia. Bars $10 \mu \mathrm{m}$ 
lateral branches, rarely intercalary, single, in chains or in clumps, and also in the cells of the macroconidia, hyaline, becoming pale brown.

Lectotype: The Netherlands, on Lilium bulbs, Dec. 1930, coll./isol. W.F. van Hell, lectotype designated here CBS H20556, culture ex-lectotype CBS 139.30.

Culture characteristics: Mycelium cottony to felty with average to strong density. Surface on OA cinnamon, with aerial mycelium sparse, buff. Surface on PDA saffron with aerial mycelium sparse buff to saffron to pale luteous. No zonation was observed, transparency was homogeneous and growth at margin even. Reverse similar to surface, except in colour, saffron to cinnamon on OA, and chestnut to sienna on PDA. Colonies on PDA grow $5-8 \mathrm{~mm}$ diam at $4^{\circ} \mathrm{C}$ after 7 days. Optimum temperature at $20^{\circ} \mathrm{C}$, when colonies reach 31-46 mm diam, after 7 days. Colony diam was $19-34 \mathrm{~mm}$ at $25^{\circ} \mathrm{C}$, after 7 days. No growth was observed at $30^{\circ} \mathrm{C}$.

Isolates studied: CBS 139.30; CBS 158.31; CBS 129083; NSAC-SH-2; NSAC-SH-2.5 (Table 1).

Hosts and distribution: Lilium sp. (bulbs), Narcissus sp. (roots) (Netherlands), Panax quinquefolium (roots) (Canada).

Notes: In the original description, Wollenweber (1931) cites Cylindrocarpon radicicola var. crassum as occurring on roots of Ulmus, Taxus and Lilium in Europe (Germany and the Netherlands). He did not designate any type specimen. However, he specifically refers to a culture sent to him by Prof. J. Westerdijk on Lilium from the CBS in the
Netherlands in 1930, which was regarded as authentic for the species. This culture is represented by CBS 139.30 (accessioned in 1930, from Lilium, the Netherlands), and thus we designate a dried, sporulating culture as lectotype for the species.

Ilyonectria cyclaminicola A. Cabral \& Crous, sp. nov. (Fig. 4)

MycoBank 560110.

Etymology: Named after the host from which it was isolated, Cyclamen sp.

Cylindrocarpi destructantis morphologice simile, sed longitudine media conidiorum longiore, 26.9-31.9 $\mu \mathrm{m}$, distinguitur.

Conidiophores simple or complex to sporodochial. Simple conidiophores arising laterally or terminally from aerial mycelium, solitary to loosely aggregated, unbranched or sparsely branched, bearing up to two phialides, 1-3-septate, 60-120 $\mu \mathrm{m}$ long; phialides monophialidic, more or less cylindrical but slightly tapering towards the tip, 20-60 $\mu \mathrm{m}$ long, $2.0-4.0 \mu \mathrm{m}$ wide at the base, $3.0-4.5 \mu \mathrm{m}$ at widest point, $1.5-2.5 \mu \mathrm{m}$ near the aperture. Conidiophores giving rise to microconidia formed by mycelium at agar surface, penicillate to mono-verticillate; phialides monophialidic, more or less cylindrical, but with slight taper towards the tip, 19-34 $\mu \mathrm{m}$ long, 1.5-2.5 $\mu \mathrm{m}$ wide at the base, $2.0-3.0 \mu \mathrm{m}$
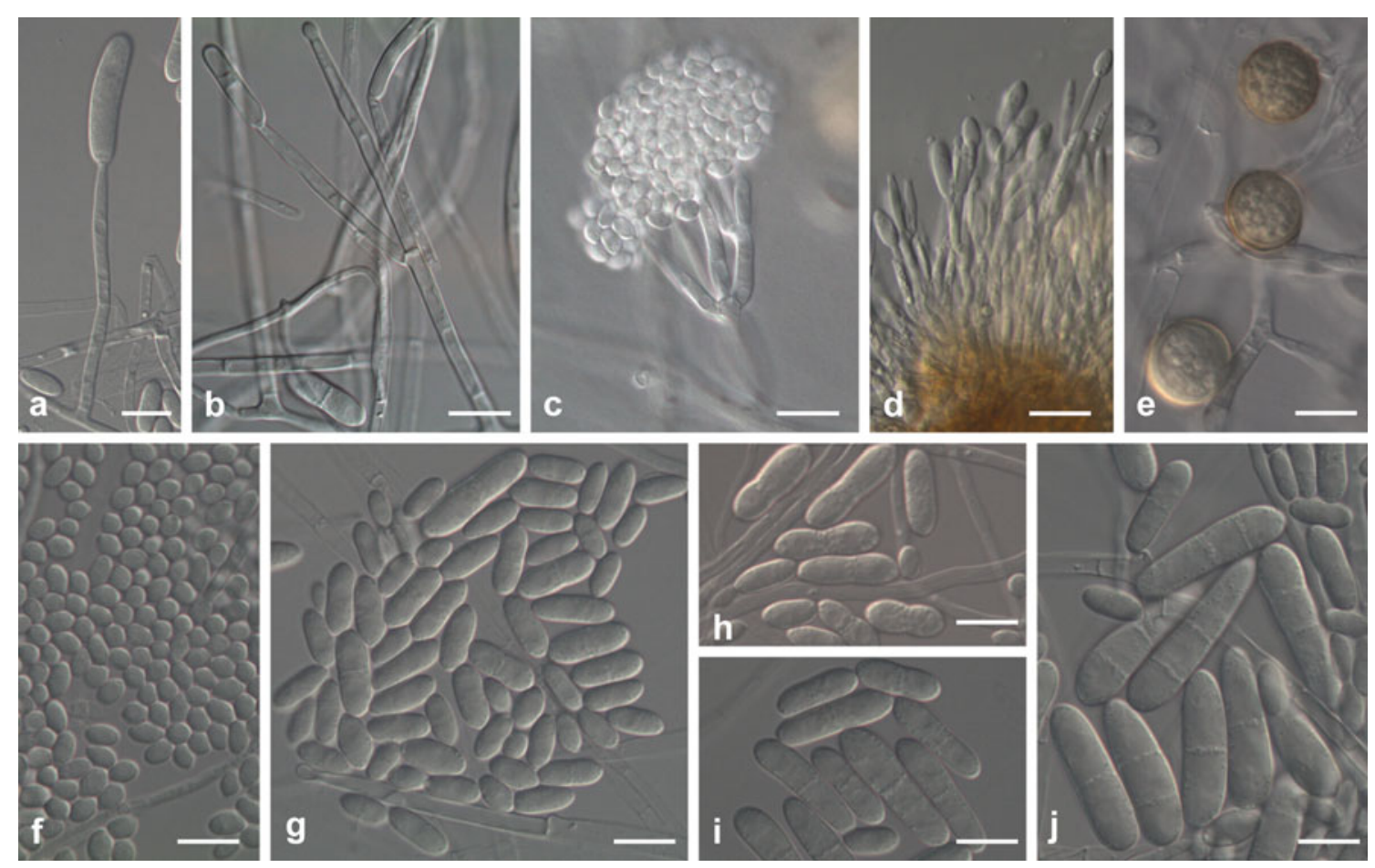

Fig. 4 Ilyonectria cyclaminicola (CBS302.93). a, b Simple conidiophores on aerial mycelium. c Pennicilate conidiophores with aseptate microconidia. d Sporodochial conidiophore on carnation leaf agar. e

Isolated chlamydospores formed in lateral branches. $\mathbf{f}-\mathbf{j}$ Micro- and macroconidia. Bars $10 \mu \mathrm{m}$ 
at widest point, 1.0-2.0 $\mu \mathrm{m}$ near the apex. Sporodochial conidiophores irregularly branched; phialides more or less cylindrical, but slightly tapering towards the tip, or narrowly flask-shaped, with widest point near the base, 14-26 $\mu \mathrm{m}$ long, 2.5-3.5 $\mu \mathrm{m}$ wide at the base 3.0-4.0 $\mu \mathrm{m}$ at widest point, $1.0-2.0 \mu \mathrm{m}$ near the apex. Macroconidia formed in flat domes of slimy masses, 1(-3)-septate, straight or minutely curved, cylindrical with both ends more or less broadly rounded, sometimes with a constriction at the septa, mostly without a visible hilum; 1-septate, (19.2)21.3-23.6 $(29.8) \times(4.4) 5.4-6.0(7.3) \mu \mathrm{m}($ av. $=22.5 \times 5.7 \mu \mathrm{m})$, with a length:width ratio of $3.4-5.5$; 2-septate, (23.8)24.0-28.4 $(29.8) \times(5.0) 5.5-7.3(8.0) \mu \mathrm{m}($ av. $=26.2 \times 6.4 \mu \mathrm{m})$, with a length:width ratio of 3.1-5.1; 3-septate, (25.3)26.9-31.9 $(33.6) \times(5.8) 5.9-6.5(6.9) \mu \mathrm{m}($ av. $=29.4 \times 6.2 \mu \mathrm{m})$, with a length:width ratio of 3.7-5.6. Microconidia formed in heads or on the agar surface, $0-1$-septate, subglobose to ovoid to subcylindrical, mostly with a visible, centrally located or slightly laterally displaced hilum; aseptate microconidia, (3.9)7.6-8.9(12.9) ×(2.2)3.6-3.9(5.4) $\mu \mathrm{m}(\mathrm{av} .=8.2 \times$ $3.7 \mu \mathrm{m})$, with a length:width ratio of $1.2-3.4$; 1 -septate,

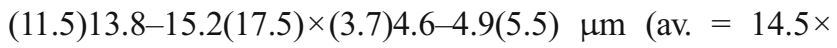
$4.7 \mu \mathrm{m}$ ), with a length:width ratio of 2.3-3.9. Chlamydospores globose to subglobose, 10-18×10-16 $\mu \mathrm{m}$, smooth, but often appearing rough due to deposits, thick-walled, formed in lateral branches, rarely intercalary, mostly isolated, hyaline, becoming medium brown.

Holotype: Netherlands, Roelofarendsveen, NAKS laboratory, Cyclamen bulb, May 1993, coll./isol. M. Hooftman, iden. E.J. Hermanides-Nijhof, holotype CBS H-20557, culture ex-type CBS 302.93.

Culture characteristics: Mycelium felty with average density. Surface on OA sepia to chestnut. Surface on PDA sepia to chestnut, with sparse, rust, aerial mycelium; no zonation was observed, and transparency was homogeneous; margins predominantly even. Reverse similar to surface, except in colour, sepia to dark brick on OA and chestnut on PDA. Colonies on PDA do not grow at $4^{\circ} \mathrm{C}$ after 7 days. Optimum temperature at $22^{\circ} \mathrm{C}$, when colonies reach $68^{-}$ $70 \mathrm{~mm}$ diam, after 7 days. Colony diam was $63-64 \mathrm{~mm}$ at $25^{\circ} \mathrm{C}$, after 7 days. No growth was observed at $30^{\circ} \mathrm{C}$.

Isolate studied: CBS 302.93 (Table 1).

Host and distribution: Bulb of Cyclamen sp. (Netherlands).

Ilyonectria europaea A. Cabral, Rego \& Crous, sp. nov. (Fig. 5)

\section{MycoBank 560103.}

Etymology: Named after the European continent, where this fungus appears to be widely distributed.
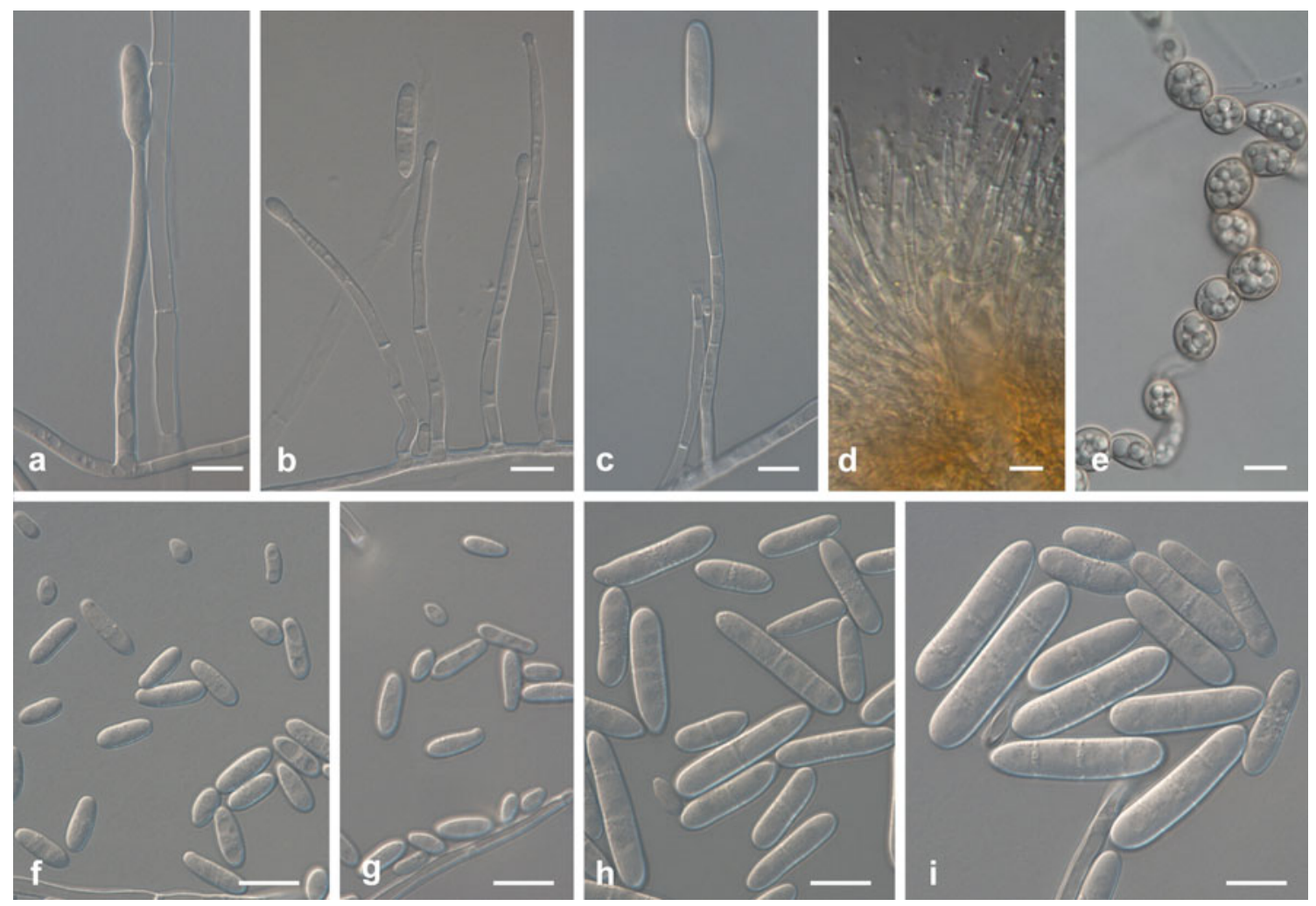

Fig. 5 Ilyonectria europaea (CBS 129078). a-c Simple conidiophores on aerial mycelium. d Sporodochial conidiophore on carnation leaf agar. e Chlamydospores in aerial mycelium. f-i Micro- and macroconidia. Bars $10 \mu \mathrm{m}$ 
Ilyonectriae robustae morphologice similis, sed longitudine media macroconidiorum breviore, 29.7-31.5 $\mu \mathrm{m}$, distinguitur.

Conidiophores simple or complex to sporodochial. Simple conidiophores arising laterally or terminally from aerial mycelium, solitary to loosely aggregated, unbranched or sparsely branched, bearing up to three phialides, 1-3-septate, 50-120 $\mu \mathrm{m}$ long; phialides monophialidic, cylindrical to subulate, 26-60 $\mu \mathrm{m}$ long, 2.5$3.5 \mu \mathrm{m}$ wide at the base, 1.5-2.5 $\mu \mathrm{m}$ near the apex. Complex conidiophores aggregated in small sporodochia (on carnation leaf), repeatedly and irregularly branched. Macroconidia predominating, formed on both type of conidiophores, on SNA formed in flat domes of slimy masses, 1(-3)-septate, straight or minutely curved, cylindrical with both ends more or less broadly rounded, but may narrow towards the tip, mostly without a visible hilum; 1-septate, (16.4)21.9-23.4(34.0) ×(4.0)5.2-5.6(7.8) $\mu \mathrm{m}($ av. $=22.7 \times 5.4 \mu \mathrm{m})$, with a length:width ratio of $3.2-$ 5.4; 2-septate, (22.0)26.4-28.1(34.0) ×(4.4)5.9-6.4(8.0) $\mu \mathrm{m}($ av. $=27.2 \times 6.1 \mu \mathrm{m})$, with a length:width ratio of 3.4-6.4; 3-septate, (22.0)29.7-31.5(40.0) ×(5.0)6.5-6.9 (8.6) $\mu \mathrm{m}($ av. $=30.6 \times 6.7 \mu \mathrm{m})$, with a length:width ratio of 3.5-6.0. Microconidia 0-1-septate, ellipsoid to ovoid, more or less straight, without a visible hilum; aseptate microconidia sometimes curved towards one end, (3.0) 8.5-9.8(17.0) ×(1.7)3.3-3.5(5.0) $\mu \mathrm{m}(\mathrm{av} .=9.1 \times 3.4 \mu \mathrm{m})$, with a length:width ratio of 1.5-3.4; 1-septate, (9.2)13.4$14.6(18.9) \times(3.0) 4.0-4.4(5.9) \mu \mathrm{m}(\mathrm{av} .=14.0 \times 4.2 \mu \mathrm{m})$, with a length:width ratio 2.6-4.0. Conidia formed in heads or on simple conidiophores as white (OA) or unpigmented (SNA) masses. Chlamydospores globose to subglobose, 9$14 \times 7-14 \mu \mathrm{m}$, smooth, but often appearing rough due to deposits, thick-walled, terminal on short or long lateral branches or intercalary, single, in chains or in clumps, golden-brown.

Holotype: Portugal, Vidigueira, at basal end of a 2-yearold Vitis vinifera plant; scion Petit Verdot, rootstock 110R, 2008, coll./isol. C. Rego, holotype CBS H-20558, culture ex-type CBS 129078=Cy241=CPC 19165.

Culture characteristics: Mycelium felty with average density. Surface on OA chestnut, with saffron aerial mycelium. Sienna to saffron on PDA, with luteous aerial mycelium. Concentric zonation, with homogeneous transparency, margins predominantly even. Reverse similar to surface, except in the colour; sepia on OA, and chestnut to umber on PDA. Colonies on PDA grow poorly, 1-5 mm diam at $4^{\circ} \mathrm{C}$ after 7 days. Optimum temperature for growth is $22^{\circ} \mathrm{C}$, when colonies reach $43-57 \mathrm{~mm}$ diam, after 7 days. Colony diam was $37-47 \mathrm{~mm}$ at $25^{\circ} \mathrm{C}$, after 7 days. No growth was observed at $30^{\circ} \mathrm{C}$.

Isolates studied: Cy131; Cy155; CBS 537.92; CBS 102892; CBS 129078 (Table 1).
Hosts and distribution: Actinidia chinensis 'Hayward' (internal lesion of stem) (France), Aesculus hippocastanum (wood) (Belgium), Phragmites australis (stem) (Germany), Vitis vinifera (Portugal).

Ilyonectria gamsii A. Cabral \& Crous, sp. nov. (Fig. 6)

\section{MycoBank 560112.}

Etymology: Named after Prof. dr. Walter Gams, who has made a major contribution to our knowledge of Hypocrealean soil fungi.

Ilyonectriae panacis morphologice similis, sed longitudine media macroconidiorum breviore, 34.3-38.5 $\mu \mathrm{m}$, distinguitur.

Conidiophores simple or complex to sporodochial. Simple conidiophores arising laterally or terminally from aerial mycelium, solitary to loosely aggregated, unbranched or sparsely branched, bearing up to two phialides, 1-3septate, 50-150 $\mathrm{m}$ long; phialides monophialidic, cylindrical to subulate, 30-60 $\mu \mathrm{m}$ long, 2.5-3.5 $\mu \mathrm{m}$ wide at the base, 1.5-2.0 $\mu \mathrm{m}$ near the aperture. Sporodochial conidiophores irregularly branched; phialides cylindrical, mostly widest near the base. Macroconidia predominating, formed on simple conidiophores, on SNA formed in flat domes of slimy masses, 1-3-septate, straight, cylindrical with both ends broadly rounded, with mostly visible, centrally located hilum; 1-septate, (22.0)25.7-27.9(33.0) ×(4.0)5.1-5.5(6.0) $\mu \mathrm{m}(\mathrm{av} .=26.8 \times 5.3 \mu \mathrm{m})$, with a length:width ratio of $4.3-$ 6.2; 2-septate, (25.0)28.2-31.7(39.0) ×(5.0)5.5-5.9(6.5) $\mu \mathrm{m}$ (av. $=29.9 \times 5.7 \mu \mathrm{m})$, with a length:width ratio of 4.2-7.1; 3septate, $(24.0) 34.3-38.5(44.0) \times(5.0) 5.9-6.3(7.0) \mu \mathrm{m}(\mathrm{av} .=$ $36.4 \times 6.1 \mu \mathrm{m})$, with a length:width ratio of 4.3-7.3. Microconidia 0-1-septate, ellipsoid to subcylindrical, more or less straight, mostly with a visible hilum; aseptate microconidia (4.0)6.9-8.0(10.0) ×(3.0)4.0-4.5(5.0) $\mu \mathrm{m} \mathrm{(av.}=7.4 \times$ $4.3 \mu \mathrm{m})$, with a length:width ratio of 1.3-2.9; 1-septate, (8.0)12.9-15.7(18.0)×(4.0)4.2-4.7(5.5) $\mu \mathrm{m}$ (av. $=14.3 \times$ $4.4 \mu \mathrm{m})$, with a length:width ratio 1.8-4.0. Chlamydospores globose to subglobose to ellipsoidal, $8-14 \times 7-12 \mu \mathrm{m}$, smooth, but often appearing rough due to deposits, thickwalled, mostly intercalary, rarely terminal on short lateral branches, single, in chains or in clumps, hyaline, becoming medium brown.

Holotype: Netherlands, Lelystad, soil, June 1997, coll./ isol. J.T. Poll, iden. W. Gams, holotype CBS H-20559, culture ex-type CBS 940.97.

Culture characteristics: Mycelium cottony, dense. Surface on OA cinnamon, with sparse, buff aerial mycelium, on PDA umber to chestnut, with buff to saffron aerial mycelium; zonation absent, transparency homogeneous, margin even; reverse similar to surface, but chestnut on PDA. Colonies on PDA grow 6-7 $\mathrm{mm}$ diam at $4^{\circ} \mathrm{C}$ after 7 days. Optimum temperature at $22^{\circ} \mathrm{C}$ when colonies reach 

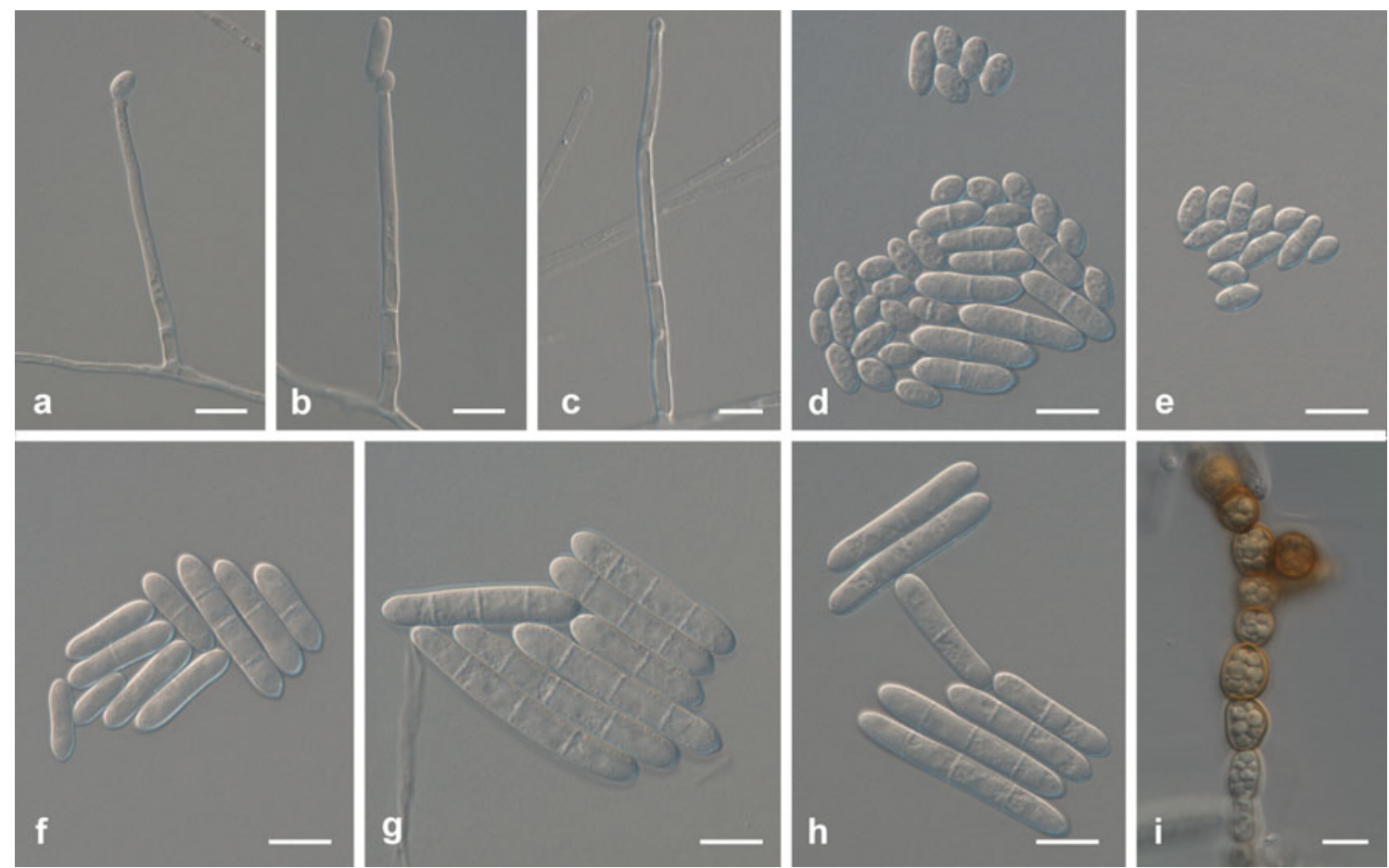

Fig. 6 Ilyonectria gamsii (CBS 940.97). a-c Simple conidiophores on aerial mycelium. d-h Micro- and macroconidia. i Chlamydospores on mycelium. Bars $10 \mu \mathrm{m}$

$44-45 \mathrm{~mm}$ diam, after 7 days. Colony diam is $22-24 \mathrm{~mm}$ at $25^{\circ} \mathrm{C}$, after 7 days. No growth observed at $30^{\circ} \mathrm{C}$.

Isolate studied: CBS 940.97 (Table 1).

Habitat and distribution: Soil (Netherlands).

\section{Ilyonectria liliigena A. Cabral \& Crous, sp. nov. (Fig. 7)}

\section{MycoBank 560114.}

Etymology: Named after its host, Lilium regale.

Ilyonectriae panacis morphologice similis, sed longitudine media macroconidiorum 3-septatorum breviore, 27.9$29.8 \mu \mathrm{m}$, distinguitur.

Conidiophores simple or complex or sporodochial. Simple conidiophores arising laterally or terminally from aerial mycelium, solitary to loosely aggregated, unbranched or sparsely branched, bearing up to two phialides, 1-4septate, 50-170 $\mu \mathrm{m}$ long; phialides monophialidic, cylindrical to subulate, $30-65 \mu \mathrm{m}$ long, $2.0-3.5 \mu \mathrm{m}$ wide at the base, 1.5-2.0 $\mu \mathrm{m}$ near the apex. Sporodochial conidiophores irregularly branched; phialides cylindrical, mostly widest near the base. Macroconidia predominating, formed on simple conidiophores, on SNA formed in flat domes of slimy masses, 1(-3)-septate, straight or frequently minutely curved, cylindrical or sometimes typically minutely widening towards the tip, therefore appearing somewhat clavate, mostly without a visible hilum; 1-septate, (19.0)22.9-24.6 $(30.0) \times(3.3) 4.2-4.5(5.2) \mu \mathrm{m}(\mathrm{av} .=23.8 \times 4.3 \mu \mathrm{m})$, with a length:width ratio of 4.0-7.0; 2-septate, (21.0)26.1-27.7 $(32.1) \times(4.0) 4.7-5(5.7) \mu \mathrm{m}(\mathrm{av} .=26.9 \times 4.9 \mu \mathrm{m})$ with a length:width ratio of 3.8-7.0; 3-septate, (23.9)27.9-29.8 $(35.0) \times(3.9) 4.7-5.1(6.0) \mu \mathrm{m}($ av. $=28.9 \times 4.9 \mu \mathrm{m})$, with a length:width ratio of 4.0-8.3. Microconidia 0-1-septate, ellipsoidal to subcylindrical, more or less straight, mostly with a visible hilum; aseptate, microconidia (5.9)8.9-10.3 $(17.0) \times(2.5) 3.0-3.2(4.4) \mu \mathrm{m}(\mathrm{av} .=9.6 \times 3.1 \mu \mathrm{m})$, with a length:width ratio of 2.0-4.6; 1-septate, (10.0)12.9-14.3 $(18.0) \times(2.5) 3.3-3.6(4.5) \mu \mathrm{m}(\mathrm{av} .=13.6 \times 3.4 \mu \mathrm{m})$, with a length:width ratio 2.8-5.6. Conidia formed in heads on simple conidiophores or as white (OA) or unpigmented (SNA) masses. Chlamydospores globose to subglobose, 6$14 \times 5-12 \mu \mathrm{m}$, smooth but often appearing rough due to deposits, thick-walled, mostly in terminal on short lateral branches or rarely intercalary, single, in chains or in clumps, hyaline, becoming slightly brown at margins.

Holotype: Netherlands, Hoorn, bulb rot of Lilium regale, 1949, coll./isol. M.A.A. Schipper, holotype CBS H-20560, culture ex-type CBS 189.49.

Culture characteristics: Mycelium felty, with an average to strong density. Surface on OA sienna, with sparse, saffron, aerial mycelium. Surface on PDA sepia to cinnamon, with saffron to buff aerial mycelium. Zonation absent or concentric, with homogeneous transparency. Margins were even, or sometimes slightly uneven. Reverse similar to surface, except in colour; on OA pale vinaceous 

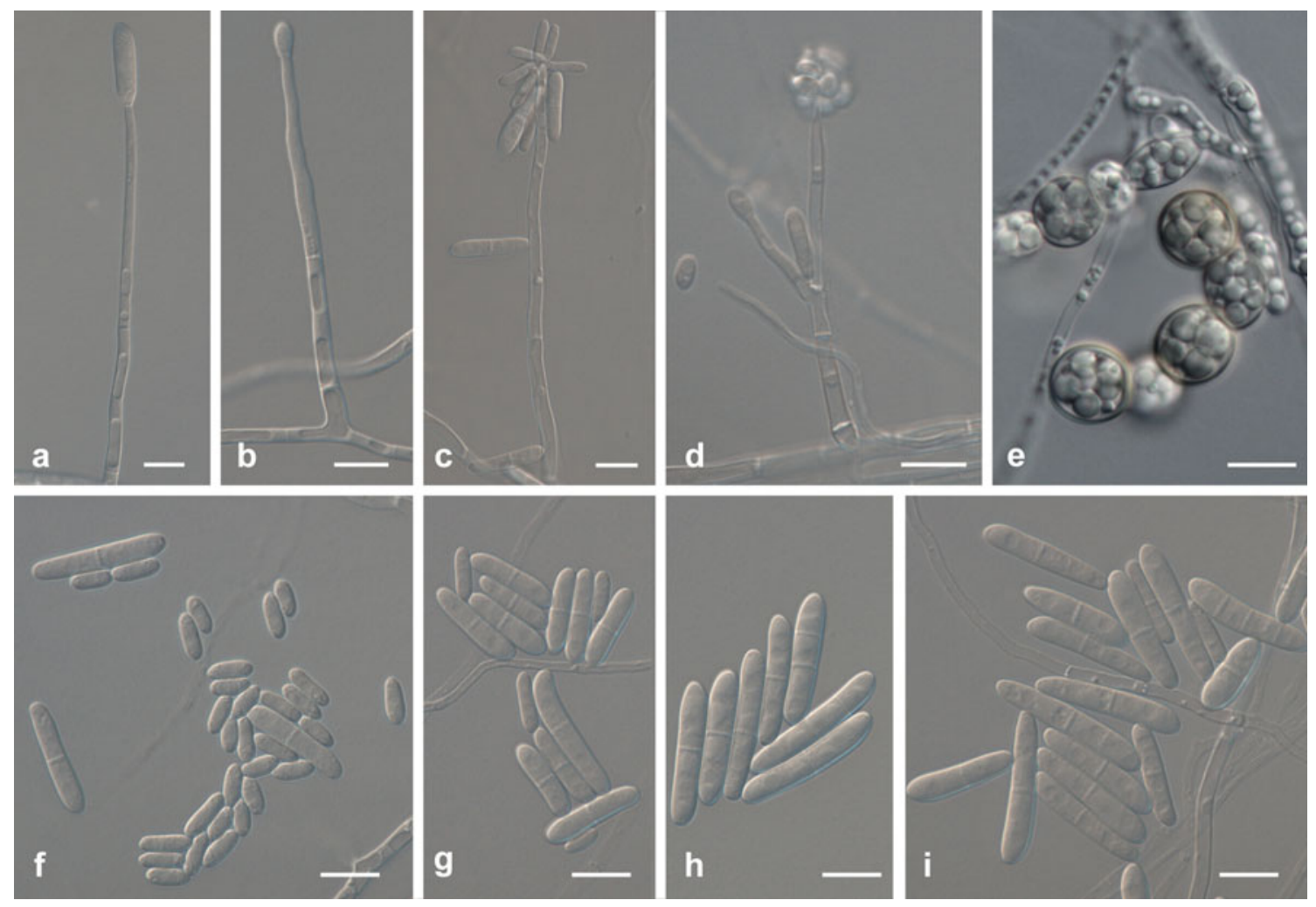

Fig. 7 Ilyonectria liliigena (CBS 189.49). a-d Simple conidiophores on aerial mycelium. e Chlamydospores on mycelium. f-i Micro- and macroconidia. Bars $10 \mu \mathrm{m}$

to cinnamon; on PDA buff to saffron to chestnut. Colonies on PDA grew poorly $\left(1-4 \mathrm{~mm}\right.$ diam) at $4^{\circ} \mathrm{C}$ after 7 days. Optimum temperature at $22^{\circ} \mathrm{C}$, when colonies reach $34-45 \mathrm{~mm}$ diam, after 7 days. Colony diam was $16-29 \mathrm{~mm}$ at $25^{\circ} \mathrm{C}$, after 7 days. No growth was observed at $30^{\circ} \mathrm{C}$.

Isolates studied: CBS 189.49; CBS 732.74; CBS 304.85; CBS 305.85 (Table 1).

Host and distribution: Lilium regale bulbs (Netherlands).

\section{Ilyonectria lusitanica A. Cabral, Rego \& Crous, sp. nov.} (Fig. 8)

\section{MycoBank 560105.}

Etymology: Named after the Latin name for the country from where it was collected, Portugal.

Ilyonectriae europaeae morphologice similis, sed longitudine media macroconidiorum breviore, 25-28.4 $\mu \mathrm{m}$, distinguitur.

Conidiophores simple or complex, sporodochial. Simple conidiophores arising laterally or terminally from aerial mycelium, solitary to loosely aggregated, unbranched or sparsely branched, bearing up to two phialides, 1-4-septate, 60-220 $\mu \mathrm{m}$ long; phialides monophialidic, cylindrical to subulate, $20-70 \mu \mathrm{m}$ long, $2.5-3.5 \mu \mathrm{m}$ wide at the base, $1.5-$
$2.5 \mu \mathrm{m}$ near the aperture. Complex conidiophores aggregated in small sporodochia, repeatedly and irregularly branched. Macroconidia predominating, formed by both type of conidiophores, on SNA formed in flat domes of slimy masses, 1(-3)-septate, straight or minutely curved, cylindrical with both ends more or less broadly rounded, but may narrow towards the tip, without a visible hilum, and may have a constriction on the septa in older cultures; 1-septate, (14.0) $17.3-18.8(21.0) \times(4.0) 4.6-5(5.5) \mu \mathrm{m}(\mathrm{av} .=18.1 \times 4.8 \mu \mathrm{m})$, with a length:width ratio of 2.8-4.8; 2-septate, (18.0)20.5$22.1(27.0) \times(4.0) 4.9-5.2(6.0) \mu \mathrm{m}(\mathrm{av} .=21.3 \times 5.1 \mu \mathrm{m})$, with a length:width ratio of 3.5-5.4; 3-septate, (18.0)25.0-28.4 $(38.0) \times(4.5) 5.2-5.5(6.0) \mu \mathrm{m}(\mathrm{av} .=26.7 \times 5.4 \mu \mathrm{m})$, with a length:width ratio of 3.6-6.8. Microconidia 0-1-septate, ellipsoid to ovoid, more or less straight, without a visible hilum, and may have a constriction at the septum; aseptate, (5.0)6.9-8.2(10.0) $\times(2.5) 3.0-3.3(4.0) \mu \mathrm{m}(\mathrm{av} .=7.6 \times 3.2 \mu \mathrm{m})$, with a length:width ratio of 1.7-3.3; 1-septate, (8.0)10.0-11.0 $(14.0) \times(3.0) 3.4-3.7(4.0) \mu \mathrm{m}(\mathrm{av} .=10.5 \times 3.6 \mu \mathrm{m})$, with a length:width ratio 2.0-3.7. Conidia formed in heads on simple conidiophores or as white (OA) or unpigmented (SNA) masses. Chlamydospores rarely observed, globose to subglobose to cylindrical, 9-13×7-11 $\mu \mathrm{m}$, smooth, but often appearing rough due to deposits, thick-walled, intercalary, hyaline, becoming slightly brown at the margin. 

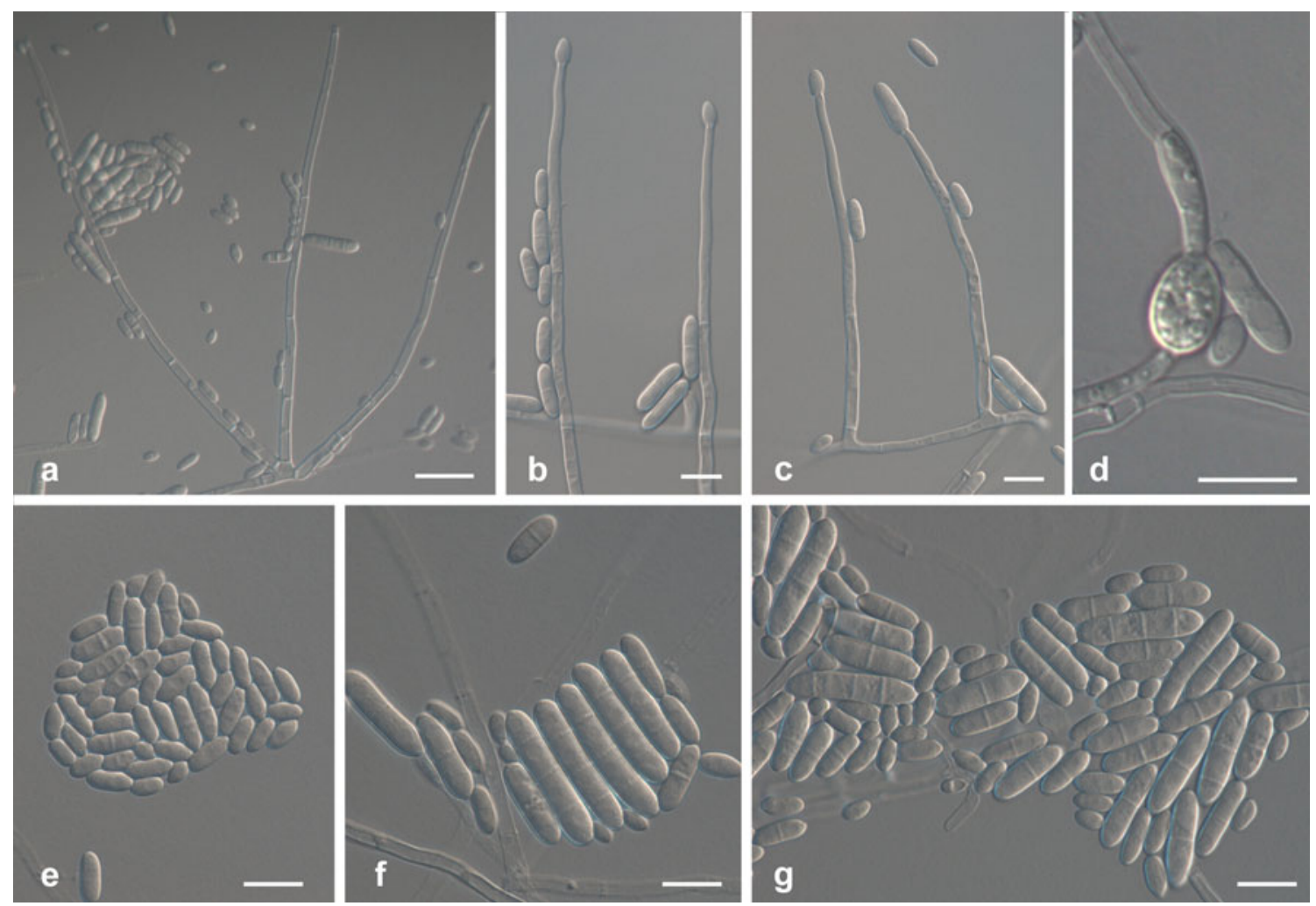

Fig. 8 Ilyonectria lusitanica (CBS 129080). a-c Simple conidiophores of the aerial mycelium. d Chlamydospores on mycelium. e-g Micro- and macroconidia. Bars (a) $20 \mu \mathrm{m}$, (b-g) $10 \mu \mathrm{m}$

Holotype: Portugal, Melgaço, Alvaredo, on Vitis vinifera, below grafting zone, 6-year-old plant; scion Alvarinho on rootstock 196-17, 2005, coll./isol. N. Cruz, holotype CBS H20563, culture ex-type CBS 129080=Cy197=CPC 19166.

Culture characteristics: Mycelium felty with average density. Surface on OA cinnamon, with aerial mycelium sparse, buff. Surface on PDA, cinnamon, with sparse, ochreous to buff aerial mycelium. Zonation absent, transparency homogeneous, margin even. Reverse similar to surface but buff to cinnamon on OA, and chestnut to cinnamon on PDA. Colonies on PDA grow $5-6 \mathrm{~mm}$ at $4{ }^{\circ} \mathrm{C}$ after 7 days. Optimum temperature between 20 and $22^{\circ} \mathrm{C}$, with colonies reaching $42-46 \mathrm{~mm}$ and $43-46 \mathrm{~mm}$, respectively, after 7 days. Colony diam was $31-32 \mathrm{~mm}$ at $25^{\circ} \mathrm{C}$, after 7 days. No growth observed at $30^{\circ} \mathrm{C}$.

Isolate studied: CBS 129080 (Table 1).

Host and distribution: Vitis vinifera (Portugal).

\section{Ilyonectria mors-panacis (A.A. Hildebr.) A. Cabral \&}

Crous, comb. nov. (Fig. 9)

\section{MycoBank 560115.}

Basionym: Ramularia mors-panacis A.A. Hildebr., Can. J. Res. 12: 101. 1935.

$=$ Cylindrocarpon panacis Matuo \& Miyaz., Trans. Mycol. Soc. Japan 9: 111. 1969. $\equiv$ Cylindrocarpon destructans f.sp. panacis Matuo \& Miyaz., Ann. Phytopath. Soc. Japan 50: 390. 1984.

Conidiophores simple or complex, sporodochial. Simple conidiophores arising laterally or terminally from aerial mycelium, solitary to loosely aggregated, unbranched or sparsely branched, rarely consisting only of phialides, 1-3septate, 45-170 $\mu \mathrm{m}$ long; phialides monophialidic, cylindrical to subulate, $23-55 \mu \mathrm{m}$ long, $2.0-3.0 \mu \mathrm{m}$ wide at the base, 1.5-3.0 $\mu \mathrm{m}$ near the apex. Complex conidiophores aggregated in small sporodochia, repeatedly and irregularly branched. Macroconidia predominating, formed on simple conidiophores, on SNA formed in flat domes of slimy masses, 1(-3)-septate, straight, cylindrical with both ends more or less broadly rounded, mostly without a hilum; 1septate, (21.0)28.2-31.6(40.0)×(5.0)5.8-6.3(7.5) $\mu \mathrm{m}(\mathrm{av} .=$ $29.9 \times 6.1 \mu \mathrm{m})$, with a length:width ratio of 3.3-7.0; 2septate, (28.0)30.5-38.4(42.0)×(5.0)5.9-6.4-7.0(7.1) $\mu \mathrm{m}$ (av. $=34.4 \times 6.4 \mu \mathrm{m})$, with a length:width ratio of 4.0 $6.0 ; 3$-septate, (37.8)39.0-44.2(45.0)×(6.9)7.0-7.5(7.5) $\mu \mathrm{m}$ (av. $=41.0 \times 7.2 \mu \mathrm{m})$, with a length:width ratio of 5.3-6.0. Microconidia 0-1-septate, ellipsoid to subcylindrical, more or less straight, without a visible hilum; aseptate, (5.0)8.9-10.4(17.0) $\times(2.5) 3.6-3.9(5.0) \mu \mathrm{m}$ (av. = $9.6 \times 3.8 \mu \mathrm{m})$, with a length:width ratio of $1.3-3.4 ; 1$ septate, (9.0)12.5-14.1(19.0)×(3.5)4.4-4.8(5.5) $\mu \mathrm{m}$ (av. = $13.3 \times 4.6 \mu \mathrm{m}$ ), with a length:width ratio $2.0-4.0$. Conidia 

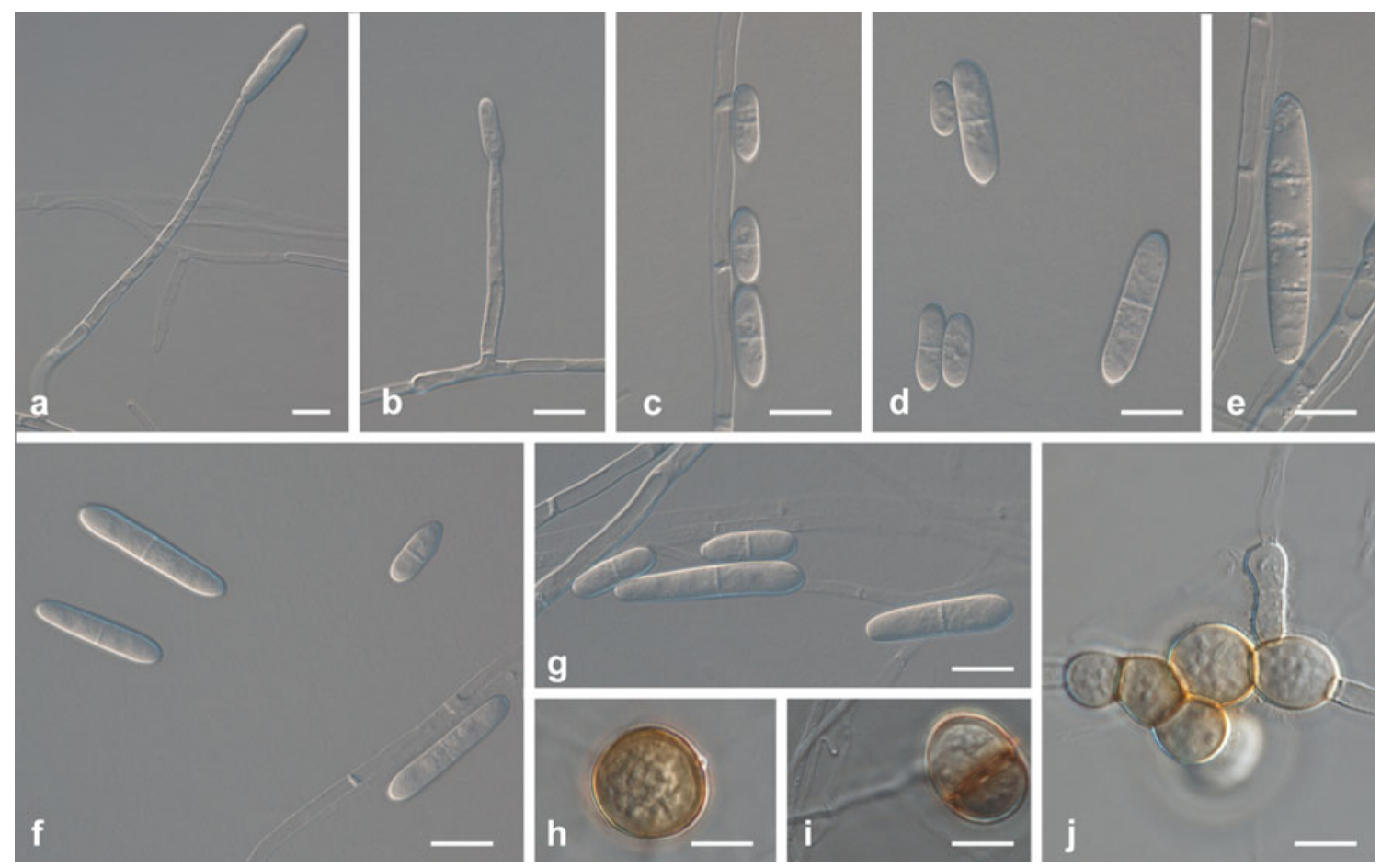

Fig. 9 Ilyonectria mors-panacis (CBS120363). a, b Simple conidiophores on aerial mycelium. c-g Micro- and macroconidia. h-j Chlamydospores on mycelium. Bars $10 \mu \mathrm{m}$

formed in heads on simple conidiophores or as white, creamy (OA) or hyaline (SNA) masses. Chlamydospores globose to subglobose, $8-16 \times 7-15 \mu \mathrm{m}$, smooth, but often appearing rough due to deposits, thick-walled, terminal on short lateral branches or intercalary, single, in chains or in clumps, hyaline, becoming medium brown.

Lectotype: Canada, Ontario, on living roots of Panax quinquefolium, June 1935, A.A. Hildebrand, lectotype designated here CBS H-20561, culture ex-lectotype CBS 306.35.

Culture characteristics: Mycelium felty with an average density. Surface on OA and PDA chestnut, with sparse, buff to rosy-buff to cinnamon or saffron aerial mycelium. Concentric zonation, with homogeneous transparency, and even margins. Reverse similar to surface, ochreous to fulvous, or sepia to dark vinaceous on $\mathrm{OA}$, and chestnut to sienna on PDA. Colonies on PDA grow $3-9 \mathrm{~mm}$ diam at $4^{\circ} \mathrm{C}$ after 7 days. Optimum temperature for growth is $18^{\circ} \mathrm{C}$, when colonies reach 22-40 mm diam, after 7 days. Colony diam was $31-40 \mathrm{~mm}$ at $25^{\circ} \mathrm{C}$ after 7 days. No growth was observed at $30^{\circ} \mathrm{C}$.

Isolates studied: CBS 306.35; CBS 307.35; CBS 120359; CBS 120360; CBS 120361; CBS 120362; CBS 120363; CBS 120364; CBS 120365; CBS 120366; CBS 120367; CBS 120368; CBS 120369; CBS 124662; CPC 13535; CPC 13537 (Table 1).

Hosts and distribution: Panax ginseng (Japan), P. quinquefolium (Canada).

Notes: Ilyonectria mors-panacis is distinct from " $C$." destructans (anamorph: "C". destructans, neotype CUP-
011985, conidia (18.0)23.0-30.0(35.0) × (6.0)6.5(7.0) $\mu \mathrm{m})$ in having larger conidia, and indistinct hila (being prominent, flat, $2 \mu \mathrm{m}$ diam in I. radicicola; see also Samuels and Brayford 1990, Fig. 1). "Ramularia" panacicola is distinct by also having shorter conidia than I. mors-panacis, 5.5$34.2 \times 2.5-7.2 \mu \mathrm{m}$ (Zinssmeister 1918), and appears to be another potential synonym of " $C$." destructans. However, no authentic material could be located of " $R$." panacicola, and the only isolate deposited under this name was a Canadian strain collected by Hildebrand (1935), which in fact represented I. mors-panacis (Fig. 1). The oldest name for the species on Panax treated here, therefore, is R. morspanacis (CBS 306.35), with the Japanese collections ("C." panacis $\equiv$ "C." destructans f.sp. panacis, CBS $124662=$ NBRC 31881) being later synonyms (see Fig. 1).

Ilyonectria panacis A. Cabral \& Crous, sp. nov. (Fig. 10)

\section{MycoBank 560104.}

Etymology: Named after its host, Panax quinquefolium.

Ilyonectriae liliigenae morphologice similis, sed longitudine media macroconidiorum longiore, $31-35 \mu \mathrm{m}$, distinguitur.

Conidiophores simple or complex, sporodochial. Simple conidiophores arising laterally or terminally from aerial mycelium, solitary to loosely aggregated, unbranched or sparsely branched bearing up to three phialides, 1-5-septate, 60-220 $\mu \mathrm{m}$ long; phialides monophialidic, cylindrical to 

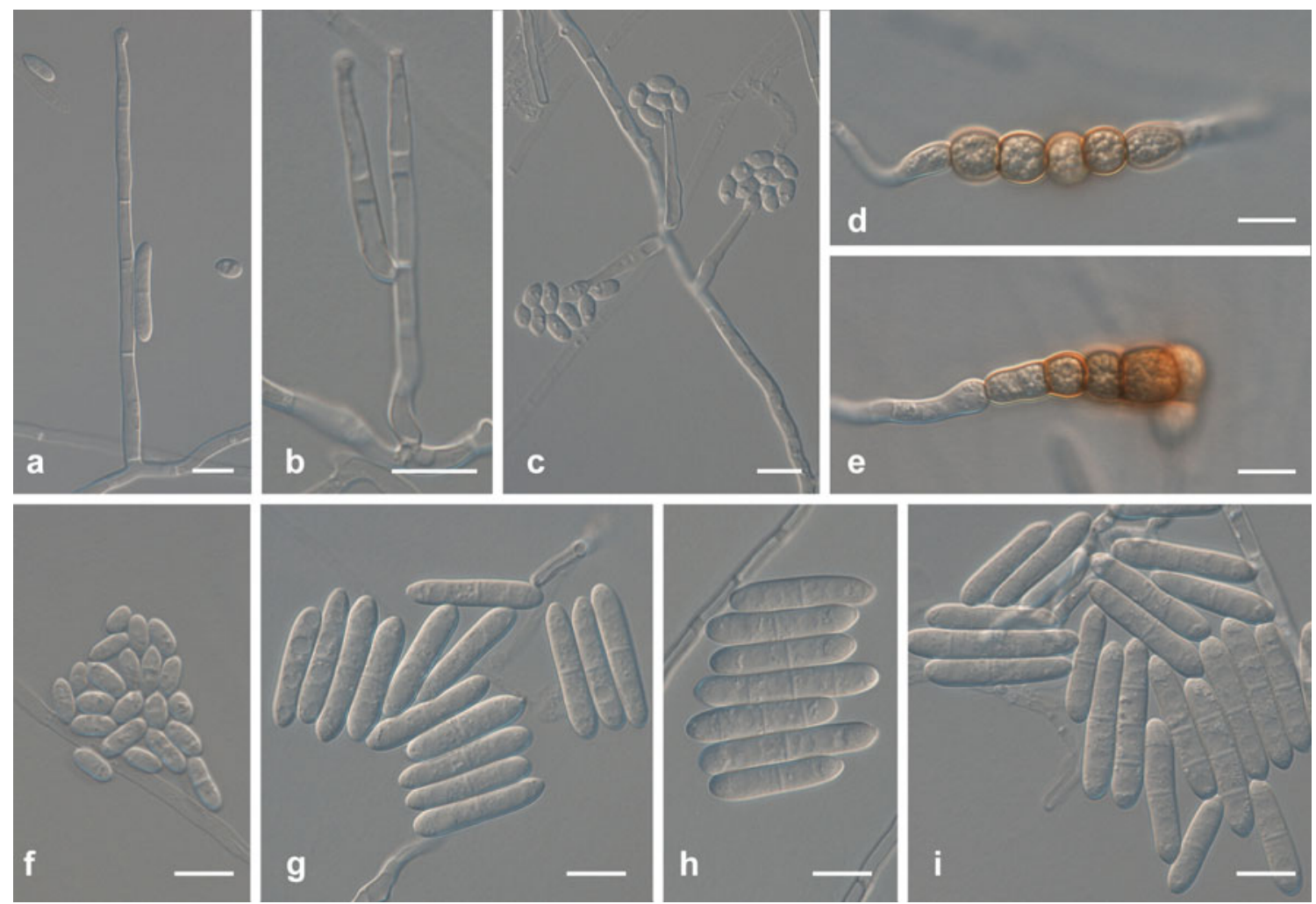

Fig. 10 Ilyonectria panacis (CBS 129079). a-c Simple, unbranched or sparsely branched conidiophores on aerial mycelium. d, e Chlamydospores on mycelium. $\mathbf{f}-\mathbf{i}$ Micro- and macroconidia. Bars $10 \mu \mathrm{m}$

subulate, 20-65 $\mu \mathrm{m}$ long, 2.5-3.0 $\mu \mathrm{m}$ wide at the base, 1.5-2.0 $\mu \mathrm{m}$ near the aperture. Complex conidiophores aggregated in small sporodochia, repeatedly and irregularly branched. Macroconidia predominating, formed on both type of conidiophores, on SNA formed in flat domes of slimy masses, 1(-3)-septate, straight, cylindrical with both ends more or less broadly rounded, mostly with a visible centrally located hilum; 1-septate, (20.0)23.7-25.9(32.0) $\times$ (4.0)4.7-5.0(5.5) $\mu \mathrm{m}($ av. $=24.8 \times 4.8 \mu \mathrm{m})$, with a length: width ratio of 4.0-6.0; 2-septate, (23.0)27.0-30.3(37.0) $\times$ (4.8)5.0-5.4(6.0) $\mu \mathrm{m}$ (av. $=28.7 \times 5.2 \mu \mathrm{m})$, with a length: width ratio of $4.6-6.7$; 3-septate, $(27.0) 31.2-35.0(49.0) \times$ (5.0)5.4-5.8(6.0) $\mu \mathrm{m}$ (av. $=33.1 \times 5.6 \mu \mathrm{m})$, with a length: width ratio of 4.9-8.2. Microconidia 0-1-septate, ellipsoid to ovoid to subcylindrical, more or less straight, mostly with a visible hilum; aseptate, (6.0)8.0-9.8(13.0) $\times(3.5)$ 3.7-3.9(4.0) $\mu \mathrm{m}(\mathrm{av} .=8.9 \times 3.8 \mu \mathrm{m})$, with a length:width ratio of 1.7-3.3; 1 -septate, (8.0)11.3-13.7(16.0) $\times(3.5) 3.8-$ $4.2(4.5) \mu \mathrm{m}(\mathrm{av} .=12.5 \times 4.0 \mu \mathrm{m})$, with a length:width ratio 1.8-4.3. Conidia formed in heads on simple conidiophores or as white (OA) or unpigmented (SNA) masses. Chlamydospores globose to subglobose to ellipsoidal, $8-14 \times 6$ $10 \mu \mathrm{m}$, smooth, but often appearing rough due to deposits, thick-walled, terminal on short lateral branches or interca- lary, single, in chains or in clumps, hyaline, becoming medium brown.

Holotype: Canada, Alberta, Panax quinquefolium, 1998, coll./isol. K. F. Chang, holotype CBS H-20562, culture ex-type CBS 129079=CDC-N-9A=CPC 19167.

Culture characteristics: Mycelium felty with strong density. Surface on OA chestnut to sienna, with aerial mycelium sparse, vinaceous-buff. Surface on PDA chestnut to cinnamon, with aerial mycelium sparse, buff to saffron. No zonation was observed, and transparency was homogeneous; margins predominantly even. Reverse similar to surface, except in the colour, fawn to cinnamon on OA, and chestnut on PDA. Colonies on PDA grow $5 \mathrm{~mm}$ diam at $4^{\circ} \mathrm{C}$ after 7 days. Optimum temperature at $20^{\circ} \mathrm{C}$, with colonies reaching $40-42 \mathrm{~mm}$ diam, after 7 days. Colony diam was $15 \mathrm{~mm}$ at $25^{\circ} \mathrm{C}$ after 7 days. No growth observed at $30^{\circ} \mathrm{C}$.

Isolate studied: CBS 129079 (Table 1).

Host and distribution: Panax quinquefolium (Canada).

Notes: Several species have in the past been described on Panax in the genera Ramularia and Cylindrocarpon. The only unresolved species is " $C$." destructans (and its potential synonym, "Ramularia" panacicola, see above). "Cylindrocarpon" destructans is clearly different from $I$. 
panacis, which has larger conidia, (27.0)31.2-33.1-35.0 $(49.0) \times(5.0) 5.4-5.6-5.8(6.0) \mu \mathrm{m}$.

Ilyonectria pseudodestructans A. Cabral, Rego \& Crous, sp. nov. (Fig. 11)

\section{MycoBank 560106.}

Etymology: Named after its morphological similarity to "Cylindrocarpon" destructans.

Ilyonectriae crassae morphologice similis, sed macroconidiis clavatis distinguitur.

Conidiophores simple or complex, sporodochial. Simple conidiophores arising laterally or terminally from aerial mycelium, solitary to loosely aggregated, unbranched or sparsely branched, bearing up to two phialides, 1-3-septate, 50-180 $\mu \mathrm{m}$ long; phialides monophialidic, cylindrical to subulate, 30-58 $\mu \mathrm{m}$ long, 2.5-3.5 $\mu \mathrm{m}$ wide at the base, 1.5-2.0 $\mu \mathrm{m}$ near the aperture. Complex conidiophores aggregated in small sporodochia, repeatedly and irregularly branched. Macroconidia predominating, formed by simple conidiophores, on SNA formed in flat domes of slimy masses, 1-3(-4)-septate, straight, typically clavate, mostly centrally located hilum; 1-septate, (19.0)25.8-27.5(35.0) $\times$ (4.0)5.0-5.3(6.5) $\mu \mathrm{m}(\mathrm{av} .=26.7 \times 5.2 \mu \mathrm{m})$, with a length: width ratio of 3.8-6.6; 2-septate, (23.0)30.0-31.7(38.0)× (5.0)5.3-5.5(6.0) $\mu \mathrm{m}(\mathrm{av} .=30.9 \times 5.4 \mu \mathrm{m})$, with a length: width ratio of 4.3-7.4; 3-septate, (28.0)34.2-36.2(48.0) $\times$ (5.0)5.9-6.2(7.0) $\mu \mathrm{m}(\mathrm{av} .=35.2 \times 6.0 \mu \mathrm{m})$, with a length: width ratio of 4.6-7.4. Microconidia 0-1-septate, ellipsoid to ovoid to subcylindrical, more or less straight, with a visible, centrally located hilum; aseptate (6.0)10.5-11.8 $(15.0) \times(3.0) 3.6-3.8(4.5) \mu \mathrm{m}(\mathrm{av} .=11.2 \times 3.7 \mu \mathrm{m})$, with a length:width ratio of $1.5-4.3$; 1-septate, (10.0)14.6-15.6 $(18.0) \times(3.0) 4.1-4.4(5.0) \mu \mathrm{m}(\mathrm{av} .=15.1 \times 4.2 \mu \mathrm{m})$, with a length:width ratio of 2.4-5.0. Conidia formed in heads on simple conidiophores or as white (OA) or unpigmented (SNA) masses. Chlamydospores globose to subglobose to ellipsoid, 9-18 $\times 8-14 \mu \mathrm{m}$, smooth but often appearing rough due to deposits, thick-walled, terminal on short lateral branches or intercalary, in chains or in clumps, and also in the cells of macroconidia, hyaline, becoming medium brown.

Holotype: Portugal, São Paio, Gouveia, Vitis vinifera, 4year-old, showing decline symptoms, scion Malvasia fina; rootstock 1103P, 1996, coll./isol. C. Rego, holotype CBS H20564, culture ex-type CBS 129081=Cy20=CPC 19164.

Culture characteristics: Mycelium felty, with average to strong density. Surface on OA cinnamon, with sparse, buff
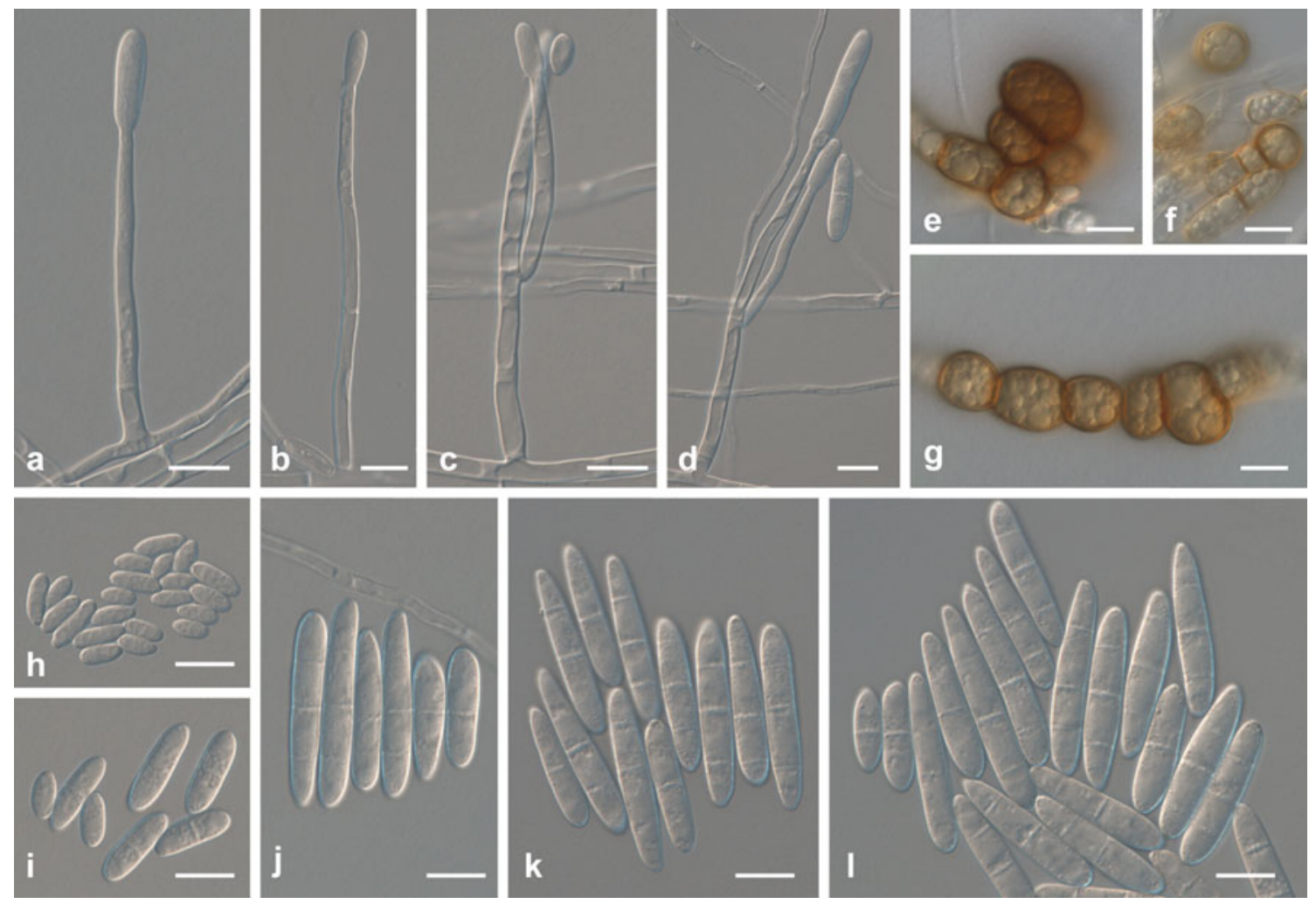

Fig. 11 Ilyonectria pseudodestructans (all from CBS 129081, except $\mathbf{g}$ and $\mathbf{e}$ from CBS117824). a-d Simple, unbranched or sparsely branched conidiophores on aerial mycelium. $\mathbf{e}-\mathbf{g}$ Chlamydospores on mycelium and macroconidia. h-l Micro- and macroconidia. Bars $10 \mu \mathrm{m}$ 
to saffron or chestnut to sienna aerial mycelium. Surface on PDA cinnamon to vinaceous, with sparse, saffron to buff or chestnut to sienna aerial mycelium. Zonation absent, with homogeneous transparency; margins even. Reverse similar to surface, except in colour, sepia to cinnamon on OA and chestnut to cinnamon on PDA. Colonies on PDA grow poorly (4-6 $\mathrm{mm}$ diam), at $4^{\circ} \mathrm{C}$ after 7 days. Optimum temperature between $20-22^{\circ} \mathrm{C}$, when colonies reach $32-$ $44 \mathrm{~mm}$ and $37-41 \mathrm{~mm}$ diam, respectively, after 7 days. Colony diam was $22-29 \mathrm{~mm}$ at $25^{\circ} \mathrm{C}$ after 7 days. No growth was observed at $30^{\circ} \mathrm{C}$.

Isolates studied: CPC 13534; CBS 117812; CBS 117824; CBS 129081; Cy22 (Table 1).

Hosts and distribution: Poa pratensis (Canada), Quercus sp. (Austria), Vitis vinifera (Portugal).

Notes: Ilyonectria pseudodestructans is reminiscent of "Cylindrocarpon" destructans, in having a similar conidial morphology (3-septate, with central, truncate hilum). However, conidia of I. pseudodestructans are somewhat longer than those of I. radicicola.
Ilyonectria robusta (A.A. Hildebr) A. Cabral \& Crous, comb. nov. (Figs. 12 and 13)

\section{MycoBank 560113.}

Basionym: Ramularia robusta A.A. Hildebr. Can. J. Res. 12: 102.1935.

Perithecia formed heterothallically in vitro, disposed solitarily or in groups, developing directly on the agar surface or on sterile pieces of birch wood, ovoid to obpyriform, with a flattened apex, up to $70 \mu \mathrm{m}$ wide, orange to red, becoming purple-red in $3 \% \mathrm{KOH}$ (positive colour reaction), smooth to warted, up to $250 \mu \mathrm{m}$ diam and high; perithecial wall consisting of two regions; outer region 11-36 $\mu \mathrm{m}$ thick, composed of 1-3 layers of angular to subglobose cells, $10-30 \times 6-24 \mu \mathrm{m}$; cell walls up to $1 \mu \mathrm{m}$ thick; inner region 8-14 $\mu \mathrm{m}$ thick, composed of cells that are flat in transverse optical section and angular to oval in

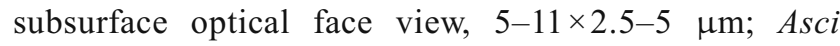
narrowly clavate to cylindrical, $40-50 \times 4.5-6 \mu \mathrm{m}, 8$ spored; apex subtruncate, with a minutely visible ring.

Fig. 12 Ilyonectria robusta (a, b from CPC $13532 \times$ CBS 308.35; $\mathbf{c}-\mathbf{k}$ from CPC $13532 \times$ CBS 117813). a, b Development of perithecia on the surface of a birch toothpick or agar. $\mathbf{c}-\mathbf{e}$ Perithecium mounted in lactic acid. d Ostiolar area. e Surface view of perithecium wall region. $\mathbf{f}-\mathbf{h}$ Longitudinal sections of perithecia showing details of ostiole and wall. $\mathbf{i}-\mathbf{k}$ Asci and ascospores. Bars (a-c) $50 \mu \mathrm{m}$; (d, f) $20 \mu \mathrm{m} ;(\mathbf{e}, \mathbf{g}-\mathbf{k}) 10 \mu \mathrm{m}$
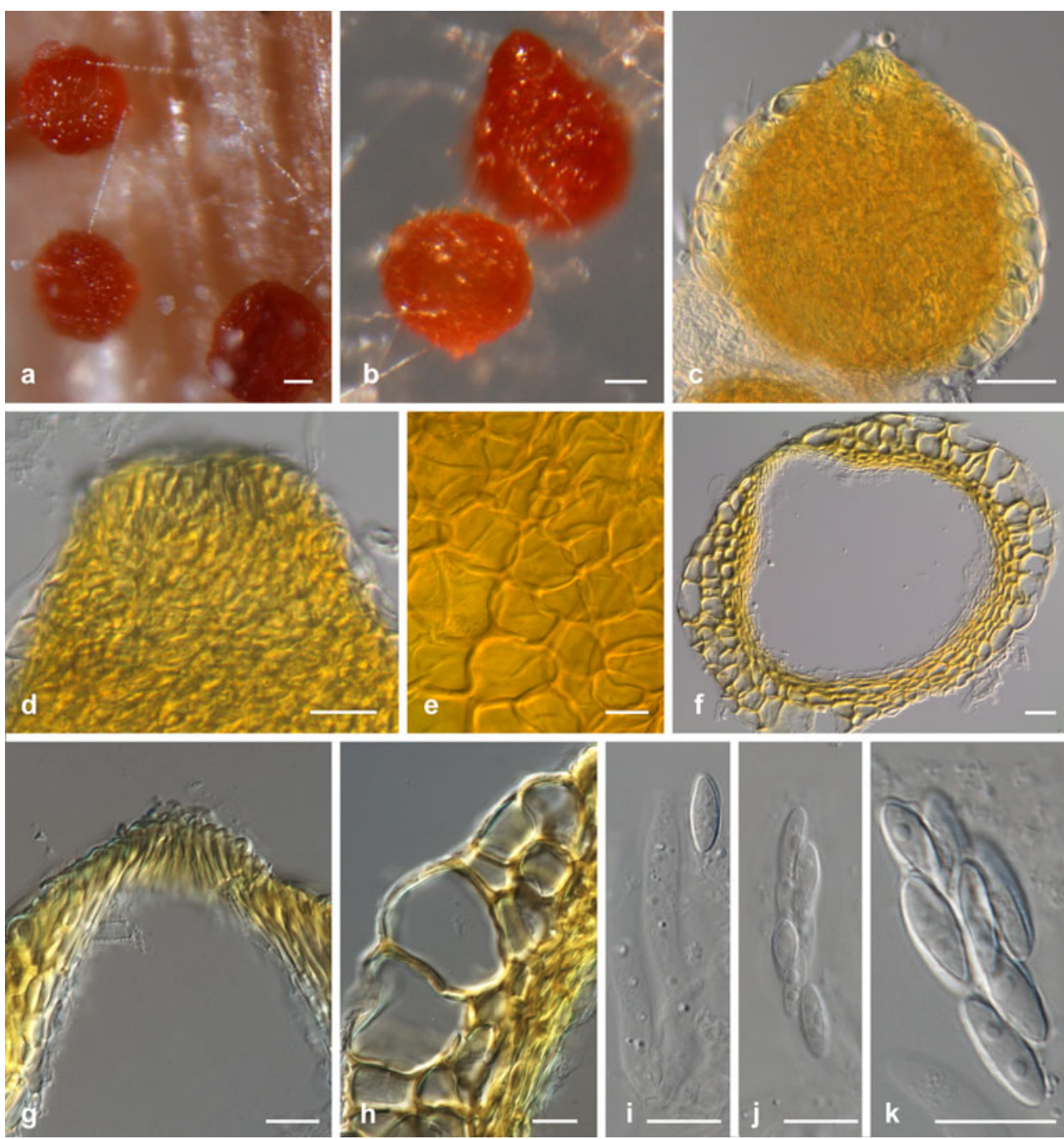


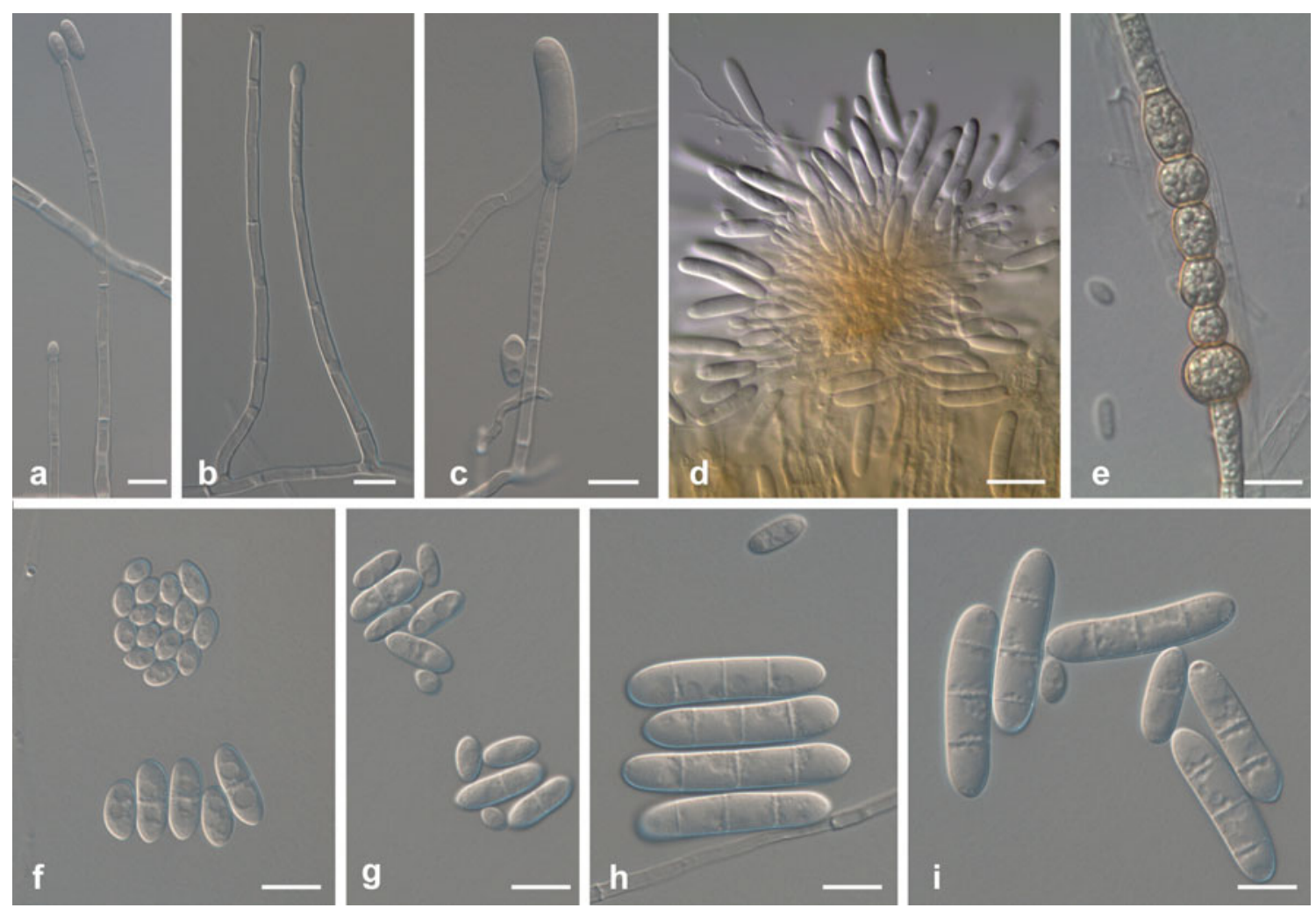

Fig. 13 Ilyonectria robusta (All from CBS 129084, except f from CBS 605.92). a-c Simple conidiophores on aerial mycelium. d Sporodochial conidiophore on carnation leaf agar. e Chlamydospores on mycelium $\mathbf{f}-\mathbf{i}$ Micro- and macroconidia. Bars $10 \mu \mathrm{m}$

Ascospores medianly 1-septate, ellipsoid to oblongellipsoid, somewhat tapering towards both ends, smooth to finely warted, frequently guttulate, hyaline, (8.2)9.4-9.7$10.0(11.5) \times(2.5) 2.9-3.0-3.1(3.7) \mu \mathrm{m}$. Conidiophores simple or complex or sporodochial. Simple conidiophores arising laterally or terminally from aerial mycelium, solitary to loosely aggregated, unbranched or sparsely branched, bearing up to three phialides, 1-4-septate, $55-160 \mu \mathrm{m}$ long; phialides monophialidic, cylindrical to subulate, $20-60 \mu \mathrm{m}$ long, 2.0-3.0 $\mu \mathrm{m}$ wide at the base, $1.5-2.0 \mu \mathrm{m}$ near the apex. Complex conidiophores aggregated in small sporodochia (on carnation leaf agar; Crous et al. 2009b), repeatedly and irregularly branched; phialides more or less cylindrical, but tapering slightly in the upper part towards the apex, or narrowly flask-shaped, mostly with widest point near the middle, 15-20 $\mu \mathrm{m}$ long, 2.5-3.5 $\mu \mathrm{m}$ wide at the base, $3.0-4.0 \mu \mathrm{m}$ at the widest point, and $1.0-2.0 \mu \mathrm{m}$ wide near the apex. Macroconidia predominating, formed on simple conidiophores, on SNA formed in flat domes of slimy masses, 1-3-septate, straight, minutely curved or sometimes distorted, cylindrical with both ends more or less broadly rounded, but may narrow towards the tip, mostly without a visible hilum; 1-septate, (15.0)22.8-24.6(35.0)× (4.5)6.3-6.7(8.0) $\mu \mathrm{m}(\mathrm{av} .=23.7 \times 6.5 \mu \mathrm{m})$, with a length: width ratio of 2.7-5.2; 2-septate, (20.0)26.2-28.1(38.0) $\times$
(5.0)6.9-7.2(8.0) $\mu \mathrm{m}(\mathrm{av} .=27.2 \times 7.0 \mu \mathrm{m})$, with a length: width ratio of $2.9-5.2 ; 3$-septate, $(24) 32.3-34.7(58) \times(6.0)$ $7.2-7.5(9.0) \mu \mathrm{m}(\mathrm{av} .=33.5 \times 7.4 \mu \mathrm{m})$, with a length:width ratio of 3.1-7.3. Microconidia $0-1$-septate, ellipsoid to ovoid to subcylindrical, more or less straight, without a visible hilum; aseptate, (4.0)8.0-9.3(14.0)×(2.5)3.6-4.0(5.5) $\mu \mathrm{m}$ (av. $=8.7 \times 3.8 \mu \mathrm{m})$, with a length:width ratio of $1.3-4.0$; 1-septate, (9.0)13.5-14.7(18.0)×(3.5)4.7-5.1(6.0) $\mu \mathrm{m} \mathrm{(av.} \mathrm{=}$ $14.1 \times 4.9 \mu \mathrm{m})$, with a length:width ratio $1.5-4.5$. Conidia formed in heads on simple conidiophores or as white (OA) or unpigmented (SNA) masses. Chlamydospores globose to subglobose, 7-14×6-13 $\mu \mathrm{m}$, smooth, but often appearing rough due to deposits, thick-walled, mostly occurring intercalary in chains, hyaline, becoming golden-brown.

Lecto- and teleotype: Canada, Ontario, on living roots of Panax quinquefolium, 1935, A.A. Hildebrand, lectotype designated here CBS H-20565, as dried culture of CBS 308.35; teleotype designated here CBS H-20566, including fertile perithecia of the teleomorph (CPC $13532 \times$ CBS 308.35), culture ex-lectotype CBS 308.35 .

Fertile matings: Perithecia observed after $4 \mathrm{wk}$ in crossings of strains: CPC $13532 \times$ CBS 308.35 , CPC $13532 \times$ CBS 773.83, CPC $13532 \times$ CBS 605.92, CPC $13532 \times$ CBS 117813 , CBS $129084 \times$ CBS 308.35 , CBS $129084 \times$ CBS 605.92 , CBS $129084 \times$ CBS 117813 . 
Culture characteristics: Mycelium felty with an average density. Surface on OA sienna to sepia with aerial mycelium sparse, buff. Surface on PDA cinnamon, with aerial mycelium buff to cinnamon, or rosy buff on PDA. Zonation absent to concentric, with homogeneous transparency; margins predominantly even, but sometimes uneven. Reverse similar to surface, except in the colour, sienna on $\mathrm{OA}$ and chestnut at the centre, and sienna to orange towards the margin on PDA. Colonies on PDA grow $4-7 \mathrm{~mm}$ at $4{ }^{\circ} \mathrm{C}$ after 7 days. Optimum temperature at $22^{\circ} \mathrm{C}$ when colonies reach 40-52 $\mathrm{mm}$ diam, after 7 days. Colony diam was 35$48 \mathrm{~mm}$ at $25^{\circ} \mathrm{C}$ after 7 days. No growth to slight growth (0$2 \mathrm{~mm}$ ) was observed at $30^{\circ} \mathrm{C}$.

Isolates studied: CBS 321.34; CBS 308.35; CBS 773.83; CBS 605.92; CBS 117813; CBS 117814; CBS 117815; CBS 117817; CBS 117818; CBS 117819; CBS 117820; CBS 117821; CBS 117822; CBS 117823; CBS 129084; CD1666; CPC 13532; Cy23; Cy158; Cy231 (Table 1).

Hosts and distribution: Loroglossum hircinum (root) (Tunisia), Panax quinquefolium (root) (Canada), Prunus cerasus, Thymus sp., Vitis vinifera (basal end of rootstock) (Portugal), Quercus robur (root), Quercus sp. (root) (Austria), Tilia petiolaris (rootstock) (Germany), water (in aquarium with Anodonta sp.) (Netherlands).

Notes: When Hildebrand (1935) described Ramularia robusta from living roots of Panax quinquefolium in
Ontario, Canada, he did not indicate a type specimen. However, he deposited an original culture in the CBS. A sporulating, dried-down culture is thus herewith designated as lectotype, and a new name proposed in Ilyonectria, with a teleotype represented by a fertile mating between CPC $13532 \times$ CBS 308.35 .

\section{Ilyonectria rufa A. Cabral \& Crous, sp. nov. (Fig. 14)}

\section{MycoBank 560116.}

Etymology: The epithet "rufa" referring to "Coleomyces rufus", a provisional name proposed for this species by Moreau and Moreau (1937).

Ilyonectriae crassae morphologice similis, sed macroconidiis brevioribus, 28-31.2 $\mu \mathrm{m}$ longis, distinguitur.

Conidiophores simple or complex, sporodochial. Simple conidiophores arising laterally or terminally from aerial mycelium, solitary to loosely aggregated, unbranched or sparsely branched, bearing up to two phialides, 1-5-septate, 55-210 $\mu \mathrm{m}$ long; phialides monophialidic, cylindrical to subulate, 20-57 $\mu \mathrm{m}$ long, 2.5-3.5 $\mu \mathrm{m}$ wide at the base, 1.5-2.0 $\mu \mathrm{m}$ near the aperture. Complex conidiophores aggregated in small sporodochia, repeatedly and irregularly branched. Macroconidia predominating, formed on both types of conidiophores, on SNA formed in flat domes of slimy masses, 1(-3)-septate, straight, cylindrical with both
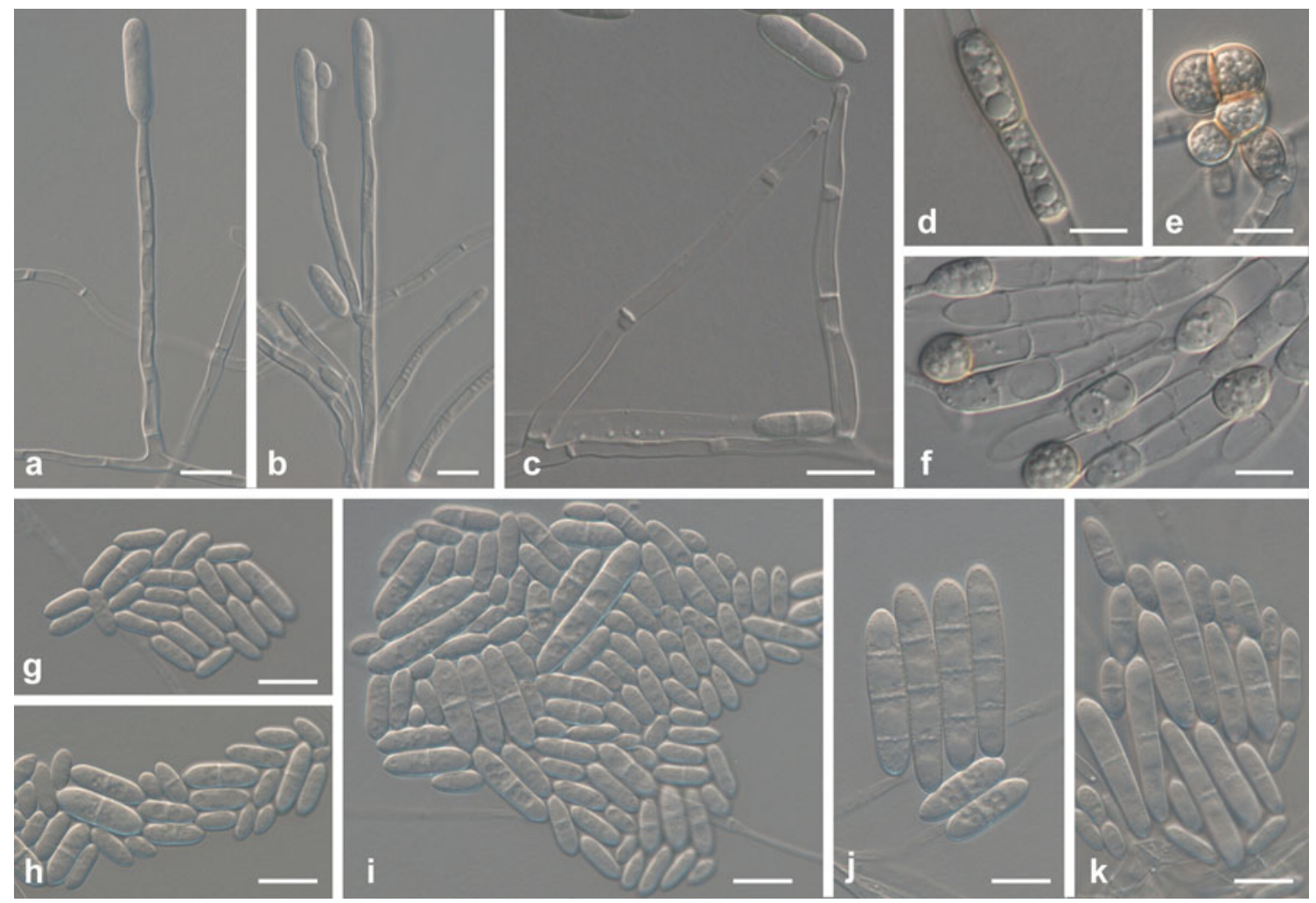

Fig. 14 Ilyonectria rufa (All from CBS 156.47, except $\mathbf{c}$ from CBS 120372). a-c Simple, sparsely branched conidiophores on aerial mycelium. d-f Chlamydospores in mycelium and in macroconidia. g-k Micro- and macroconidia. Bars $10 \mu \mathrm{m}$ 
ends broadly round, mostly centrally located hilum; 1septate, (17.0)22.3-23.8(29.0) ×(4.0)5.1-5.4(6.0) $\mu \mathrm{m}$ (av. = $23.1 \times 5.3 \mu \mathrm{m})$, with a length:width ratio of $3.1-5.6$; 2 septate, (19.0)24.5-26.6(32.0) $\times(4.0) 5.2-5.5(6.5) \mu \mathrm{m} \mathrm{(av.} \mathrm{=}$ $25.5 \times 5.4 \mu \mathrm{m})$, with a length:width ratio of 3.4-6.0; 3-septate, (23.0)28.6-31.2(37.0) ×(5.0)5.5-5.9(7.0) $\mu \mathrm{m}(\mathrm{av} .=29.9 \times$ $5.7 \mu \mathrm{m})$, with a length:width ratio of 3.4-7.2. Microconidia 0-1-septate, ellipsoid to subcylindrical, more or less straight, with a visible, centrally located hilum; aseptate, (4.0)8.4-9.8 $(15.0) \times(3.0) 3.5-3.8(5.0) \mu \mathrm{m}(\mathrm{av} .=9.1 \times 3.6 \mu \mathrm{m})$, with a length:width ratio of $1.3-4.0 ; 1$-septate, (9.0)12.1-13.3 $(17.0) \times(3.0) 4.2-4.6(5.5) \mu \mathrm{m}(\mathrm{av} .=12.7 \times 4.4 \mu \mathrm{m})$, with a length:width ratio 2.2-3.8. Conidia formed in heads on simple conidiophores or as white (OA) or unpigmented (SNA) masses. Chlamydospores globose to subglobose to cylindrical, 7-12×6-9 $\mu \mathrm{m}$, smooth, but often appearing rough due to deposits, thick-walled, terminal on short, lateral branches, or intercalary, single, in chains or in clumps, and also in the cells of the macroconidia, hyaline, becoming slightly brown in the outer wall.

Holotype: France, dune sand, Feb. 1937, coll./isol. F. Moreau, holotype CBS H-20567, culture ex-type CBS 153.37.

Culture characteristics: For CBS 153.37, CBS 156.47, CPC 13536 and 94-1628: Mycelium felty with average to strong density. Surface on OA buff to saffron, aerial mycelium sparse, buff. On PDA rosy-buff to cinnamon, with aerial mycelium sparse, buff to rosy-buff or pale luteus in the centre. For CBS 640.77, CBS 120371 and CBS 120372: Mycelium felty, with low to average density. Surface on OA cinnamon to sienna, aerial mycelium sparse, saffron to cinnamon. On PDA saffron to cinnamon, with aerial mycelium cinnamon to rust. Zonation absent or concentric, with homogeneous transparency; margins even or sometimes uneven. Reverse similar, except in colour, saffron on OA, and cinnamon to rosy-buff on PDA, or sienna with pigments, pale vinaceous in OA and umber to chestnut on PDA. Colonies on PDA grow poorly, (2-7 mm diam) at $4^{\circ} \mathrm{C}$, after 7 days. Optimum temperature between $20-22^{\circ} \mathrm{C}$, when colonies reach $28-42 \mathrm{~mm}, 31-46 \mathrm{~mm}$ diam, respectively, after 7 days. Colony diam was 19$24 \mathrm{~mm}$ at $25^{\circ} \mathrm{C}$ after 7 days. No growth observed at $30^{\circ} \mathrm{C}$.

Isolates studied: CBS 153.37; CBS 156.47; CBS 640.77; CBS 120371; CBS 120372; CPC 13536; 941628 (Table 1).

Hosts and distribution: Azalea indica (Belgium), dune sand (France), Picea glauca, Pseudotsuga menziesii (Canada).

Notes: The genus Coleomyces represents a later synonym of Cylindrocarpon (Booth 1966). However, Coleomyces, which is based on C. rufus (Moreau and Moreau 1937), was published as "ad interim", suggesting that Moreau and Moreau were planning to validate the name later, which was not the case. Based on the International Code of Botanical Nomenclature (Art. 34.1, Ex. 6), Chaverri et al. (2011) correctly chose to ignore the name. However, an original strain of C. rufus was deposited in the CBS (CBS 153.37), and the species epithet is herewith validated for the species.

\section{Ilyonectria venezuelensis A. Cabral \& Crous, sp. nov.}

(Fig. 15)

\section{MycoBank 560117.}

Etymology: Named after the country from where it was collected, Venezuela.

Ilyonectriae robustae morphologice similis, sed conidiophoris cum verticillo terminali phialidum distinguitur.

Conidiophores simple or complex, sporodochial. Simple conidiophores arising laterally or terminally from aerial mycelium or from agar surface, solitary to loosely aggregated, unbranched, or bearing terminal, penicillate phialides, 1-4-septate, 35-200 $\mu \mathrm{m}$ long; phialides monophialidic, cylindrical to subulate, 40-60 $\mu \mathrm{m}$ long, 2.5$3.5 \mu \mathrm{m}$ wide at the base, 1.5-2.5 $\mu \mathrm{m}$ near the apex, or narrowly flask-shaped, 16-40 $\mu \mathrm{m}$ long, 2.0-3.0 $\mu \mathrm{m}$ wide at the base, 3.0-4.0 $\mu \mathrm{m}$ at the widest point, 1.5-2.5 $\mu \mathrm{m}$ near the apex. Complex conidiophores aggregated in small sporodochia, repeatedly and irregularly branched. Macroconidia predominating, formed by both types of conidiophores, on SNA formed in flat domes of slimy masses, 1-3septate, straight or minutely curved, cylindrical with both ends more or less broadly rounded, but may narrow towards the tip, mostly without a visible hilum; 1-septate, (22.0)24.6-27.3(35.0) ×(5.0)5.3-5.7(6.5) $\mu \mathrm{m}(\mathrm{av} .=26.0 \times$ $5.5 \mu \mathrm{m})$, with a length:width ratio of 3.8-7.0; 2-septate, (25.0)26.3-37.4(44.0)×(5.9)6.0-6.6(7.0) $\mu \mathrm{m}$ (av. $=31.9 \times$ $6.3 \mu \mathrm{m})$, with a length:width ratio of 4.2-6.8; 3-septate, (28.0)36.5-41.7(50.0)×(6.0)6.9-7.5(8.0) $\mu \mathrm{m}(\mathrm{av} .=39.1 \times$ $7.2 \mu \mathrm{m})$, with a length:width ratio of 4.0-6.7. Microconidia 0-1-septate, ellipsoid to ovoid, more or less straight, without a visible hilum; aseptate, (5.0)8.4-10.5(13.0) $\times$ (3.0)3.3-3.7(4.0) $\mu \mathrm{m}($ av. $=9.5 \times 3.5 \mu \mathrm{m})$, with a length: width ratio of $1.7-3.4$; 1 -septate, (11.0)14.5-16.3(19.0) $\times$ (3.5)3.9-4.3(5.0) $\mu \mathrm{m}(\mathrm{av} .=15.4 \times 4.1 \mu \mathrm{m})$, with a length: width ratio 2.8-4.8. Conidia formed in heads on simple conidiophores or as white (OA) or unpigmented (SNA) masses. Chlamydospores ovoid to ellipsoidal, 6-13 $\times 5$ $7 \mu \mathrm{m}$, smooth, but often appearing rough due to deposits, thick-walled, terminal on short lateral branches or intercalary, single, in chains or in clumps, hyaline, becoming slightly brown at the margin.

Holotype: Venezuela, Amazonas, Cerro de la Neblina, tree bark, 1985, coll./isol. A. Rossman, holotype CBS H20568, culture ex-type CBS 102032.

Culture characteristics: Mycelium cottony with average to strong density. Surface on OA saffron, with aerial 

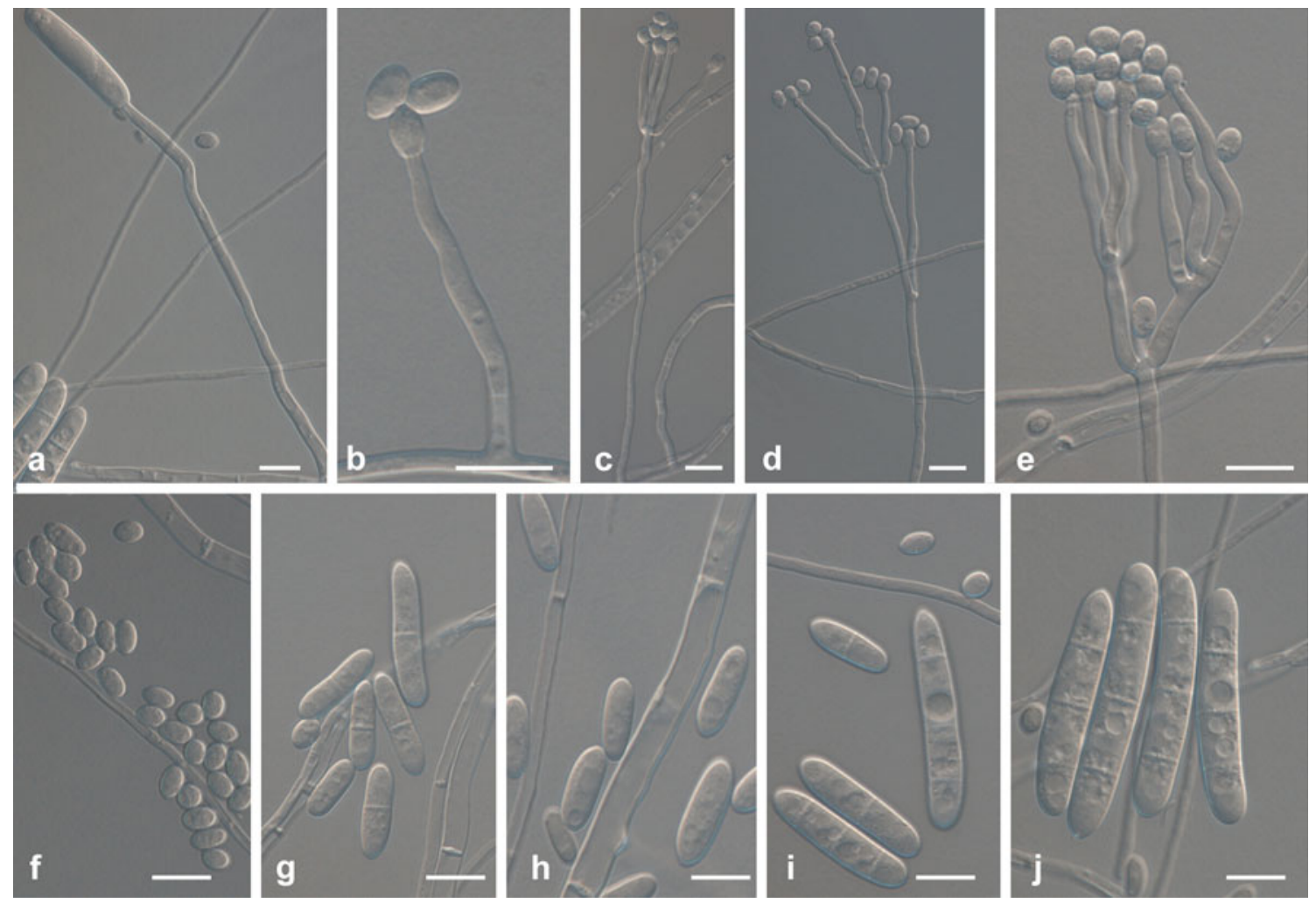

Fig. 15 Ilyonectria venezuelensis (CBS 102032). a, b Simple conidiophores on aerial mycelium. c-e Conidiophores bearing terminal, penicillate phialides. $\mathbf{f}-\mathbf{j}$ Micro- and macroconidia. Bars $10 \mu \mathrm{m}$

mycelium sparse, buff, on PDA buff to saffron, with aerial mycelium saffron to pale luteous; zonation absent, transparency homogeneous, margin even; reverse similar to surface, but saffron to cinnamon on PDA. Colonies on PDA grow poorly $(2-3 \mathrm{~mm})$ at $4^{\circ} \mathrm{C}$, after 7 days. Optimum temperature at $20^{\circ} \mathrm{C}$, with colonies reaching $49 \mathrm{~mm}$ diam, after 7 days. Colony diam was $35-36 \mathrm{~mm}$ at $25^{\circ} \mathrm{C}$ after 7 days. No growth was observed at $30^{\circ} \mathrm{C}$.

Isolate studied: CBS 102032 (Table 1).

Host and distribution: Tree bark (Venezuela).

\section{Ilyonectria vitis A. Cabral, Rego \& Crous, sp. nov.}

(Fig. 16)

\section{MycoBank 560107.}

Etymology: Named after the host from which it was collected, Vitis vinifera.

Ilyonectriae anthuriicolae morphologice similis, sed longitudine media macroconidiorum longiore, 41.6$43.5 \mu \mathrm{m}$, distinguitur.

Conidiophores simple or complex or sporodochial. Simple conidiophores arising laterally or terminally from aerial mycelium, solitary to loosely aggregated, unbranched or sparsely branched, bearing up to three phialides, 1-3 septate, 30-70 $\mu \mathrm{m}$ long; monophialides more or less cylindrical, but tapering slightly towards the tip, 11-
$21 \mu \mathrm{m}$ long, 2.0-3.0 $\mu \mathrm{m}$ wide at the base, $3.0-4.5 \mu \mathrm{m}$ at widest point, $1.5-2.5 \mu \mathrm{m}$ near the apex. Conidiophores forming microconidia arising from mycelium at agar surface, reduced to monophialides, or a stipe with a terminal arrangement of phialides, ranging from 2 to a dense cluster; sparsely branched or penicillate; monophialides narrowly flask-shaped, typically with widest point near the middle, $10-17 \mu \mathrm{m}$ long, $1.5-3.0 \mu \mathrm{m}$ wide at the base, $2.5-4.0 \mu \mathrm{m}$ at widest point, $1.0-2.0 \mu \mathrm{m}$ near the apex. Sporodochial conidiophores irregularly branched; phialides more or less cylindrical but slightly tapering towards the tip, or narrowly flask-shaped, with widest point near the middle, 14-20 $\mu \mathrm{m}$ long, 2.5-3.5 $\mu \mathrm{m}$ wide at the base, 3.0$4.5 \mu \mathrm{m}$ at widest point, $1.5-2.5 \mu \mathrm{m}$ near the apex. Macroconidia formed in flat domes of slimy masses, predominantly 3-septate, rarely 1-2- or 4-septate, straight or minutely curved, cylindrical with both ends more or less broadly rounded, mostly without a visible hilum; 3-septate conidia (34.9)41.6-43.5(51.6) $\times(6.2) 7.9-8.2(9.5) \mu \mathrm{m} \quad(\mathrm{av} .=42.5 \times$ $8.0 \mu \mathrm{m}$ ), with a length:width ratio of 3.9-6.7. Microconidia on SNA formed in heads, aseptate, subglobose to ovoid, rarely ellipsoid, mostly with a visible, centrally located or slightly laterally displaced hilum, (3.7)4.9-5.4(6.7) $\times(3.2)$ 3.7-4.0(4.6) $\mu \mathrm{m}($ av. $=5.1 \times 3.9 \mu \mathrm{m})$, with a length:width ratio of 1.1-1.7. Chlamydospores globose to subglobose to ellipsoid, 9-18×6-13 $\mu \mathrm{m}$, smooth, but often appearing 

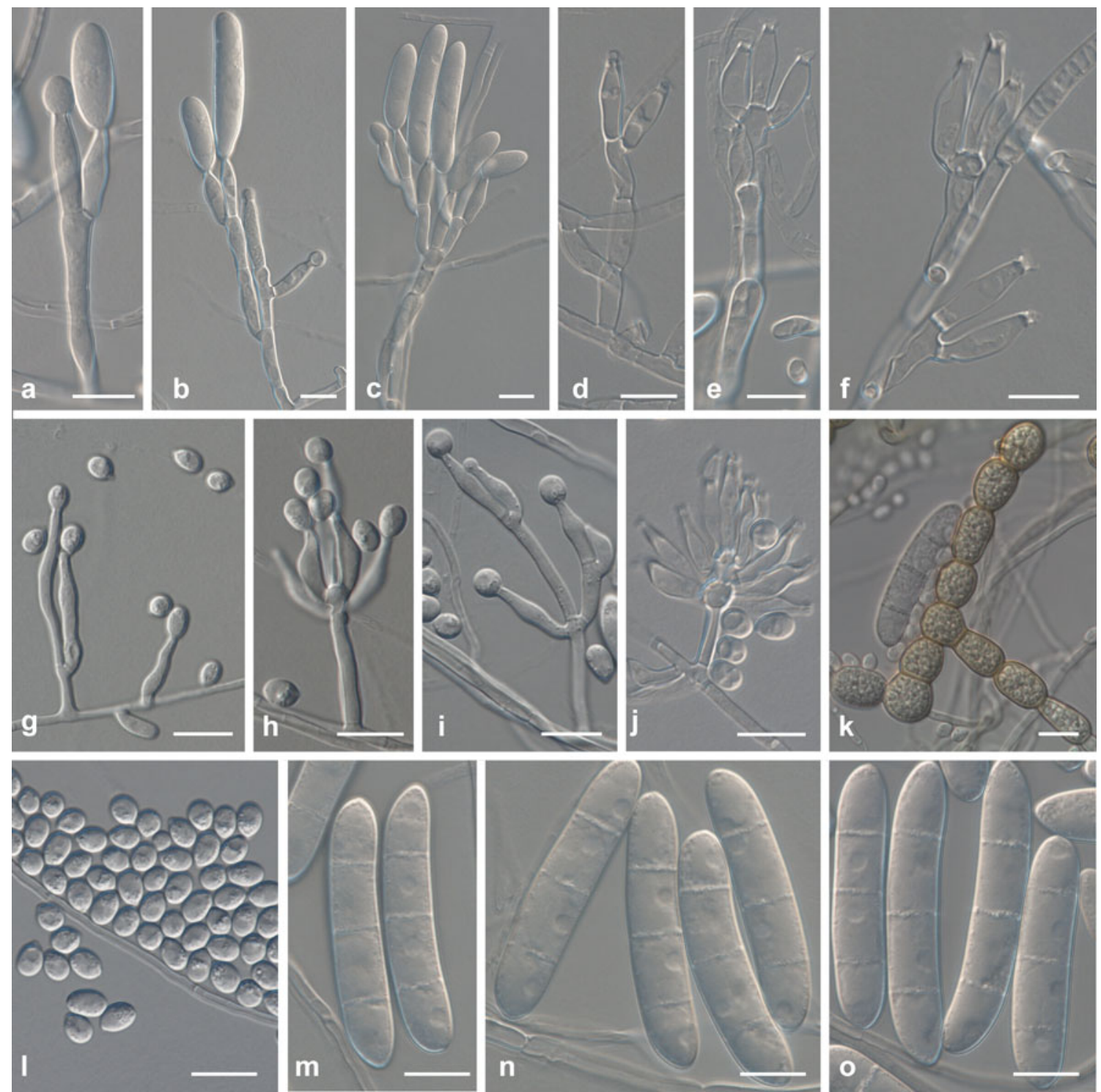

Fig. 16 Ilyonectria vitis (CBS 129082). a-c Simple conidiophores on aerial mycelium. $\mathbf{d}-\mathbf{g}$ Conidiophores forming microconidia arising from mycelium at agar surface, reduced to a stipe with a terminal arrangement of phialides, ranging from 2 to a dense cluster; sparsely branched or penicillate. $\mathbf{i}-\mathbf{l}$ Micro- and macroconidia. m Chlamydospores on mycelium. Bars $10 \mu \mathrm{m}$ rough due to deposits, thick-walled, formed intercalary in chains or in clumps, and also in the cells of macroconidia, hyaline, becoming golden-brown.

Holotype: Portugal, Vidigueira, Vitis vinifera, basal end of a 2-year-old plant; scion Touriga Nacional; rootstock 110R, 2008, coll./isol. C. Rego, holotype CBS H-20569, culture ex-type CBS 129082=Cy233=CPC 19168.

Culture characteristics: Mycelium felty with density low to average. Surface on OA sienna, with sparse, saffron aerial mycelium, and luteous growth at margin. Surface on PDA chestnut, with sienna aerial mycelium, with luteous margin. Zonation was absent (OA) or concentric (PDA), transparency was homogeneous (PDA) or not (OA). Growth at margin even to uneven. Reverse similar to surface, except in colour, sienna to saffron on OA, and chestnut to umber on PDA. Colonies on PDA do not grow at $4^{\circ} \mathrm{C}$ after 7 days. Optimum temperature at $20^{\circ} \mathrm{C}$, when colonies reach $29-30 \mathrm{~mm}$ diam, after 7 days. Colony diam was $39-40 \mathrm{~mm}$ at $25^{\circ} \mathrm{C}$ and $8-9 \mathrm{~mm}$ at $30^{\circ} \mathrm{C}$ after 7 days. No growth was observed at $35^{\circ} \mathrm{C}$.

Isolate studied: CBS 129082 (Table 1).

Host and distribution: Vitis vinifera (Portugal).

Key to species treated

1 Growth at margin on $\mathrm{OA}$ after 14 days at $20^{\circ} \mathrm{C}$, lacking yellow pigmentation

2 Colony diameter on PDA after 7 days at $25^{\circ} \mathrm{C}<30 \mathrm{~mm}$ 
3 Macroconidia forming chlamydospores

4 Macroconidia 1-3-septate, 3-septate macroconidia mean range $34.1-36.2 \mu \mathrm{m}$ long

5 Macroconidia cylindrical, with the base appearing somewhat acute I. crassa

5* Macroconidia clavate I. pseudodestructans

4* Macroconidia predominantly 1-septate; 3-septate macroconidia smaller, mean range $28-31.2 \mu \mathrm{m}$ long I. rufa

3* Macroconidia lacking chlamydospores

6 Macroconidia predominantly curved I. liliigena

6* Macroconidia straight

7 Macroconidia lacking visible hilum I. mors-panacis

7* Macroconidia with a visible, centrally located hilum

8 Three-septate macroconidia mean range 31.0-35.0 $\mu \mathrm{m}$ long I. panacis

8* Three-septate macroconidia mean range 34.3-38.5 $\mu \mathrm{m}$ long I. gamsii

2* Colony diameter after 7 days at $25^{\circ} \mathrm{C}>30 \mathrm{~mm}$

9 Colony diameter after 7 days at $25^{\circ} \mathrm{C},>50 \mathrm{~mm} \mathrm{I}$. cyclaminicola

9* Colony diameter after 7 days at $25^{\circ} \mathrm{C}, 30-50 \mathrm{~mm}$

10 Conidiophores bearing a terminal whorl of phialides $I$. venezuelensis

10* Conidiophores unbranched, or different from above

11 Teleomorph known, and can be induced in culture

12 Three-septate macroconidia mean range 32.3-34.7 $\mu \mathrm{m}$ long; ascospores mean range 9.4-10.0 $\mu \mathrm{m}$ long $I$. robusta

12* Three-septate macroconidia mean range 30.0$36.0 \mu \mathrm{m}$ long; ascospores mean range longer, 10$13 \mu \mathrm{m}$ long I. radicicola ${ }^{\mathrm{a}}$

11* Teleomorph unknown

13 Mean range of 3-septate macroconidia, 29.7-31.5 $\times$ 6.5-6.9 $\mu \mathrm{m}$ I. europaea

13* Mean range of 3-septate macroconidia smaller, 25.0$28.4 \times 5.2-5.5 \mu \mathrm{m} \mathrm{I}$. lusitanica

1* Yellow pigmentation present at margin

14 Macroconidia 3-septate, mean range 29.5-32.2 $\mu \mathrm{m}$ long I. anthuriicola

14* Macroconidia 3-septate, mean range 41.6-43.5 $\mu \mathrm{m}$ long I. vitis

${ }^{a}$ No authentic cultures of " $C$." destructans, conidia $(18.0-) 23.0-30.0(-35.0) \times(6.0-) 6.5(-7.0) \mu \mathrm{m}$, are presently available.

\section{Discussion}

"Cylindrocarpon" destructans is a cosmopolitan soil-borne pathogen causing disease on a wide number of herbaceous and woody plant species (Samuels and Brayford 1990). The wide morphological and pathogenic amplitude of " $C$." destructans makes it a commonly identified species, with many diseases from the Cylindrocarpon-complex being attributed to it, and ranking at the top of all "Cylindrocarpon" spp. deposited in the NCBI nucleotide database.

In this study, " $C$." destructans isolates from the CBS culture collection (deposited under the wider concept of the species) were analysed using a multigene approach in order to clarify taxonomic aspects of this species complex. Molecular analyses show that these isolates cluster in various clades supported by high bootstrap support values. A previous study (Seifert et al. 2003) included a subset of the strains used here, and already highlighted the existence of unexpected divergence in "C." destructans, as opposed to a large homogeneity in e.g. Neonectria ditissima. Several species have in recent years been separated from the "C." destructans complex, including " $C$." macroconidialis, "C." coprosmae and "C." austroradicicola based on morphological (Samuels and Brayford 1990) and molecular characters (Schroers et al. 2008; Seifert et al. 2003). Furthermore, several isolates causing black foot disease of grapevine, previously considered as "C." destructans, were recently identified as I. liriodendri (Chaverri et al. 2011; Halleen et al. 2006), along with the ex-type strain from Liriodendron tulipifera (CBS 110.81) and a strain from Cyclamen (CBS 301.93). In this study, two further strains isolated from young Malus domestica and Quercus suber trees showing decline symptoms were also identified as I. liriodendri.

Altogether, we analysed 68 strains putatively belonging to " $C$." destructans, but none of them clustered together with the ex-type culture of I. radicicola (CBS 264.65), suggesting that this species may not be as common as previously accepted. Halleen et al. (2006) identified a single strain (IMI 313237, isolated from arecoid palm) clustering with CBS 264.65. This also raises questions relating to the correlation between the anamorph, "C." destructans, and its purported teleomorph, I. radicicola.

"Nectria" radicicola was described by Gerlach and Nilson (1963) from decayed leaves, flowers stalks and corms of Cyclamen persicum collected in Sweden, with a "Cylindrocarpon" anamorph they identified as " $C$." radicicola.

In 1924, Wollenweber introduced " $C$." radicicola (McAlpine) Wollenw. as a new combination, based on Septocylindrium radicicola McAlpine (1899), described from Citrus trees in Australia. Later, Wollenweber (1928) noted that Septocylindrium radicicola, with catenulate conidia, was different from " $C$." radicicola, and the name was therefore based on Wollenweber's (1928) description. Because of this confusion in names, Booth (1966) suggested that " $C$." radicicola should be dropped, and that the name to be used as anamorph for I. radicicola should be "C." destructans [originally described by Zinssmeister (1918) on Panax quinquefolia from Wisconsin, USA]. 
Furthermore, Booth (1966) designated a neotype for " $C$." destructans, obtained from $P$. quinquefolia in USA, KY, Washington Co., Springfield; collected by W.B. Edwards in 1922, available as herbarium material in Cornell Plant Pathology Herbarium, CUP-011985. This specimen was re-examined in the present study [conidia (18.0)23.0$30.0(35.0) \times(6.0) 6.5(7.0) \mu \mathrm{m}$ ] [original description by Zinssmeister (1918), 9.0-32.4×3.2-8.1 $\mu \mathrm{m}$ ], thus revealing conidia to be smaller than those formed by $I$. radicicola, which are (24.0)33.1(47.0) $\times(4.9) 6.4(7.8)$ $\mu \mathrm{m}$. From these observations, we conclude that " $C$." destructans, which occurs on P. quinquefolia in the USA, represents yet another species distinct from I. radicicola, which is not yet represented in our phylogenetic tree (Fig. 1).

A strain deposited in CBS culture collection by Hildebrand in 1935, as "Ramularia" mors-panacis, was found to represent original material (ex-type CBS 306.35), collected from living roots of Panax quinquefolium in Ontario, Canada. The epithet "mors-panacis" is therefore resurrected for this clade, while the Japanese collection identified as "Cylindrocarpon destructans" f. sp. panacis (ex-type CBS 124662=NBRC 31881), isolated from Panax ginseng in Japan, is treated as synonym.

The ex-type strain of "Ramularia" robusta (CBS 308.35), isolated from living roots of Panax quinquefolium in Ontario, Canada, can be resurrected for a large clade representing isolates from a range of hosts and continents. Similarly, an authentic strain of "C." destructans var. crassum (Booth 1966; Wollenweber 1931) is available for a species occurring on Panax and Pseudotsuga in Canada, Lilium and Narcissus in the Netherlands, and can thus be resurrected as I. crassa. Although strain CBS 120370 clustered together with other strains of $I$. crassa for most genes (no nucleotide differences in ITS and TEF, two nucleotide differences in HIS), this strain was not included in that species because of an 8-bp difference in TUB, a slower growth rate (e.g., $21 \mathrm{~mm}$ colony diam at $20^{\circ} \mathrm{C}$ for 7 days, as opposed to $31-46 \mathrm{~mm}$ for other isolates), a lower conidial length:width ratio [e.g. for 3-septate conidia 4.06.5, as opposed to 4.8-8.9 and smaller conidia (e.g. 3septate conidia ranging from $(26.0) 31.2-34.0(40.0) \times(6.0)$ 6.6-7.1(8.0) $\mu \mathrm{m}$ (av. 32.6 $\times 6.9 \mu \mathrm{m})$, as opposed to $(29.0)$

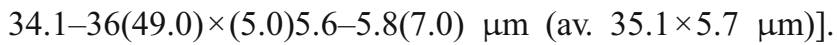
Further studies should thus be conducted in order to clarify the taxonomy of this strain.

Ilyonectria anthuriicola and I. vitis are very similar in morphology to " $C$." pauciseptatum. These species all have predominantly 3 -septate macroconidia after 10 days in culture. Ilyonectria anthuriicola is easier to distinguish than "C." pauciseptatum as the 3 -septate conidia are smaller and narrower, (25.0)29.5-32.2(38.0) ×(6.0)7.5-8.1(9.0) $\mu \mathrm{m}$, while in "C." pauciseptatum they are (37.0)42.0-47.0
$(54.0) \times(7.0) 8.5-9.5(10.0)$ (Schroers et al. 2008). For $I$. vitis 3-septate macroconidia are of similar size to those of "C." pauciseptatum, (34.9)41.6-43.5(51.6) $\times(6.2) 7.9-8.2$ (9.5), making it difficult to distinguish them based on this character. Growth rate at $20^{\circ} \mathrm{C}$ is slower in I. vitis than in "C." pauciseptatum, and they also differ regarding colony characteristics and colours. Morphologically, however, they remain difficult to distinguish.

In this study, the genetic structure of the I. radicicola complex was analysed using a multi-locus approach along with morphological and culture characters. Three major groups were identified based on this approach, each group containing several species. Although we have been able to clarify several aspects related to the host range and distribution of taxa in the I. radicicola species complex, further collections, especially from Panax in the USA, will be essential to elucidate the status of " $C$." destructans.

Acknowledgements The first author would like to thank Dr M.C. Silva (Coffee Rust Research Centre / Tropical Research Institute, Portugal) for making equipment available, and for assisting with the use of the cryostat for perithecial sectioning. Drs F. Caetano (Instituto Superior de Agronomia, Portugal), J. Armengol (Univ. Politécnica de Valencia, Spain), K.A. Seifert (Agriculture and Agri-Food, Canada), M.L. Inácio (Instituto Nacional de Recursos Biológicos/INIA, Portugal) P. Lecomte (Institut National de la Recherche Agronomique, Bordeaux-Aquitaine, France) and W.D. Gubler (Univ. California, Davis, USA) are thanked for making several strains available, without which this study would not have been possible. The curator of CUP is acknowledged for making the neotype " $C$." destructans available for examination. This article is part of a $\mathrm{PhD}$ dissertation (Instituto Superior de Agronomia, Technical University of Lisbon, Portugal). This work was partially supported by Fundação para a Ciência e a Tecnologia, Portugal (grant number SFRH/BD/ 24790/2005; project PTDC/AGR-AAM/099324/2008).

Open Access This article is distributed under the terms of the Creative Commons Attribution Noncommercial License which permits any noncommercial use, distribution, and reproduction in any medium, provided the original author(s) and source are credited.

\section{References}

Booth C (1966) The genus Cylindrocarpon. Mycol Pap 104:1-56

Brayford D, Honda BM, Mantiri FR, Samuels GJ (2004) Neonectria and Cylindrocarpon: the Nectria mammoidea group and species lacking microconidia. Mycologia 96:572-597

Castlebury LA, Rossman AY, Hyten AS (2006) Phylogenetic relationships of Neonectria/Cylindrocarpon on Fagus in North America. Can J Bot 84:1417-1433. doi:10.1139/B06-105

Chaverri P, Salgado C, Hirooka Y, Rossman AY, Samuels GJ (2011) Delimitation of Neonectria and Cylindrocarpon (Nectriaceae, Hypocreales, Ascomycota) and related genera with Cylindrocarpon-like anamorphs. Stud Mycol 68:57-78

Crous PW, Gams W, Stalpers JA, Robert V, Stegehuis G (2004a) MycoBank: an online initiative to launch mycology into the 21st century. Stud Mycol 50:19-22 
Crous PW, Groenewald JZ, Risede JM, Hywel-Jones NL (2004b) Calonectria species and their Cylindrocladium anamorphs: species with sphaeropedunculate vesicles. Stud Mycol 50:415-429

Crous PW, Slippers B, Wingfield MJ, Rheeder J, Marasas WFO, Philips AJL, Alves A, Burgess T, Barber P, Groenewald JZ (2006) Phylogenetic lineages in the Botryosphaeriaceae. Stud Mycol 55:235-253. doi:10.3114/sim.55.1.235

Crous PW, Braun U, Groenewald JZ (2007) Mycosphaerella is polyphyletic. Stud Mycol 58:1-32. doi:10.3114/sim.2007.58.01

Crous PW, Schoch CL, Hyde KD, Wood AR, Gueidan C, de Hoog GS, Groenewald JZ (2009a) Phylogenetic lineages in the Capnodiales. Stud Mycol 64:17-47. doi:10.3114/sim.2009.64.02

Crous PW, Verkleij GJM, Groenewald JZ, Samson RA (eds) (2009b) Fungal Biodiversity. CBS Laboratory Manual Series 1. Centraalbureau voor Schimmelcultures, Utrecht

de Hoog GS, Gerrits van den Ende AHG (1998) Molecular diagnostics of clinical strains of filamentous Basidiomycetes. Mycoses 41:183-189

Domsch KH, Gams W, Anderson TH (2007) Compendium of Soil Fungi, 2nd edn. IHW, Eching

Gerlach W, Nielsson L (1963) Beiträge zur Kenntnis der Gattung Cylindrocarpon Wr. V. Nectria radicicola n. sp., die bisher unbekannte Hauptfruchtform von Cylindrocarpon radicicola $\mathrm{Wr}$. Phytopathol Z 48:251-257

Glass NL, Donaldson G (1995) Development of primer sets designed for use with PCR to amplify conserved genes from filamentous ascomycetes. Appl Environ Microbiol 61:1323-1330

Gräfenhan T, Schroers H-J, Nirenberg HI, Seifert KA (2011) An overview of the taxonomy, phylogeny, and typification of nectriaceous fungi in Cosmospora, Acremonium, Fusarium, Stilbella, and Volutellax. Stud Mycol 68:79-113

Guerber JC, Correll JC (2001) Morphological description of Glomerella acutata, the teleomorph of Colletotrichum acutatum. Mycologia 93:216-229

Halleen F, Schroers H-J, Groenewald JZ, Crous PW (2004) Novel species of Cylindrocarpon (Neonectria) and Campylocarpon gen. nov. associated with black foot disease of grapevines (Vitis spp.). Stud Mycol 50:431-455. doi:10.3114/sim.55.1.227

Halleen F, Fourie PH, Crous PW (2006) A review of black-foot disease of grapevines. Phytopathol Mediterr 45:S55-S67

Hildebrand AA (1935) Root rot of ginseng in Ontario caused by members of the genus Ramularia. Can J Res 12:82-114

Hirooka Y, Kobayashi T, Natsuaki KT (2005) Neonectria castaneicola and Neo. rugulosa in Japan. Mycologia 97:1058-1066. doi:10.3852/mycologia.97.5.1058

Larkin MA, Blackshields G, Brown NP, Chenna R, McGettigan PA, McWilliam H, Valentin F, Wallace IM, Wilm A, Lopez R, Thompson JD, Gibson TJ, Higgins DG (2007) Clustal W and Clustal X version 2.0. Bioinformatics 23:2947-2948

Lombard L, Crous PW, Wingfield BD, Wingfield MJ (2010) Phylogeny and systematics of the genus Calonectria. Stud Mycol 66:31-69. doi:10.3114/sim.2010.66.03

Mantiri FR, Samuels GJ, Rahe GE, Honda B (2001) Phylogenetic relationships in Neonectria species having Cylindrocarpon anamorphs inferred from mitochondrial ribosomal DNA sequences. Can J Bot 79:334-340
Möller EM, Bahnweg G, Sandermann H, Geiger HH (1992) A simple and efficient protocol for isolation of high molecular weight DNA from filamentous fungi, fruit bodies, and infected plant tissues. Nucleic Acids Res 20:6115-6116

Moreau F, Moreau M (1937) Sur un nouveau champignon a collarette, Coleomyces rufus, nov. gen., nov. sp., ad interim. Bull Trimest Soc Mycol Fr 53:33-38

Nirenberg H (1976) Untersuchungen über die morphologische und biologische differenzierung in der Fusarium-Sektion Liseola. Mitt Biol Bundesanst Land- Forstwirtsch 169:1-117

O’Donnell K, Cigelnik E (1997) Two divergent intragenomic rDNA ITS2 types within a monophyletic lineage of the fungus Fusarium are nonorthologous. Mol Phylogenet Evol 7:103-116

O’Donnell K, Kistler HC, Cigelnik E, Ploetz RC (1998) Multiple evolutionary origins of the fungus causing Panama disease of banana: concordant evidence from nuclear and mitochondrial gene genealogies. Proc Natl Acad Sci USA 95:2044-2049

Rayner RW (1970) A Mycological Colour Chart. British Mycological Society and CAB International Mycological Institute, Kew

Rossman AY, Samuels GJ, Rogerson CT, Lowen R (1999) The genera of Bionectriaceae, Hypocreaceae and Nectriaceae (Hypocreales, Ascomycetes). Stud Mycol 42:1-248

Samuels GJ, Brayford D (1990) Variation in Nectria radicicola and its anamorph, Cylindrocarpon destructans. Mycol Res 94:433-442

Schroers H-J, Žerjav M, Munda A, Halleen F, Crous PW (2008) Cylindrocarpon pauciseptatum sp. nov., with notes on Cylindrocarpon species with wide, predominantly 3-septate macroconidia. Mycol Res 112:82-92. doi:10.1016/j.mycres.2007.10.004

Schroers H-J, Gräfenhan T, Nirenberg HI, Seifert KA (2011) A revision of Cyanonectria and Geejayessia gen. nov., and related species with Fusarium-like anamorphs. Stud Mycol 68:115-138

Seifert KA, McMullen CR, Yee D, Reeleder RD, Dobinson KF (2003) Molecular differentiation and detection of ginseng-adapted isolates of the root rot fungus Cylindrocarpon destructans. Phytopathology 93:1533-1542

Tewoldemedhin YT, Mazzola M, Mostert L, McLeod A (2010) Cylindrocarpon species associated with apple tree roots in South Africa and their quantification using real-time PCR. Eur J Plant Pathol. doi:10.1007/s10658-010-9728-4

White TJ, Bruns T, Lee S, Taylor J (1990) Amplification and direct sequencing of fungal ribosomal RNA genes for phylogenetics. In: Innis MA, Gelfand D, Sninsky JJ, White TJ (eds) PCR protocols: a guide to methods and applications. Academic, San Diego, pp 315-322

Wollenweber HW (1913) Ramularia, Mycosphaerella, Nectria, Calonectria. Eine morphologisch pathologische Studie zur Abgrenzung von Pilzgruppen mit cylindrischen und sichelförmigen Konidienformen. Phytopathology 3:198-242

Wollenweber HW (1924) Fusaria autographice delineata. 2nd edn. Berlin

Wollenweber HW (1928) Über Fruchtformen der Krebserregenden Nectriaceen. Z Parasitenk 1:138-173

Wollenweber HW (1931) Fusarium-Monographie. Fungi parasitici et saprophytici. Z Parasitenk 3:495

Zinssmeister CL (1918) Ramularia root-rots of ginseng. Phytopathology 8:557 